\title{
Tata Laksana Terapi Pasien dengan COVID-19: Sebuah Kajian Naratif
}

\author{
Adji P. Setiadi ${ }^{1,2}$, Yosi I. Wibowo ${ }^{1,2}$, Steven V. Halim ${ }^{1,2}$, Cecilia Brata ${ }^{1,2}$, \\ Bobby Presley ${ }^{1,2}$, Eko Setiawan ${ }^{1,2}$ \\ ${ }^{1}$ Pusat Informasi Obat dan Layanan Kefarmasian (PIOLK), Fakultas Farmasi, \\ Universitas Surabaya, Surabaya, Indonesia, ${ }^{2}$ Departemen Farmasi Klinis dan Komunitas, \\ Fakultas Farmasi, Universitas Surabaya, Surabaya, Indonesia
}

\begin{abstract}
Abstrak
Kasus pneumonia yang disebabkan oleh severe acute respiratory syndrome coronavirus 2 (SARS-CoV-2) yang disebut coronavirus diseases 2019 (COVID-19) oleh World Health Organization (WHO) merupakan sebuah tragedi dalam dunia kesehatan secara global. Tata laksana yang tepat dan cepat diharapkan dapat menyelamatkan nyawa pasien. Sampai tulisan ini dibuat, belum terdapat satu jenis obat yang secara resmi diizinkan penggunaannya untuk terapi COVID-19. Kajian literatur ini bertujuan untuk 1) memaparkan tata laksana pengobatan dan 2) mendaftar serta menjelaskan alternatif obat yang dapat digunakan untuk SARS-CoV-2. Proses penelusuran artikel dalam kajian pustaka ini dilakukan pada sebuah database, yakni PubMed dengan kombinasi kata kunci ((“corona virus") OR (“covid-19”) OR (“SARS-CoV-2")) AND (("treatment") OR ("therapy")). Hasil kajian ini menunjukkan bahwa tata laksana pasien dengan COVID-19 dapat berbeda antar-setting dan negara dengan mempertimbangkan ketersediaan sumber daya, khususnya obat. Pedoman terapi WHO dan pedoman di Indonesia saat ini merekomendasikan supportive therapy untuk penanganan COVID-19, antara lain: terapi untuk gejala yang terjadi, pemberian oksigen, penggunaan antibiotik, terapi cairan, penggunaan vasopresor, dan tindakan medis (termasuk pemasangan ventilator) untuk menyelamatkan nyawa pasien. Belum terdapat obat khusus yang direkomendasikan untuk menekan replikasi SARS-CoV-2. Beberapa jenis obat yang potensial bermanfaat untuk SARS-CoV-2 antara lain: klorokuin atau hidroksiklorokuin, arbidol, ribavirin, favipiravir, lopinavir/ritonavir, remdesivir, oseltamivir, dan interferon. Namun sampai dengan tulisan ini dibuat, terdapat keterbatasan bukti penelitian dengan desain yang baik yang dapat digunakan untuk menarik kesimpulan terkait superioritas suatu jenis obat tertentu dibandingkan dengan alternatif yang lain. Dalam kondisi menunggu hasil penelitian dengan desain penelitian yang baik, penggunaan obat yang memiliki bukti efektivitas (walaupun belum baik) atau diduga efektif, perlu dioptimalkan untuk menyelamatkan nyawa pasien, khususnya mereka yang dalam kondisi parah.
\end{abstract}

Kata kunci: COVID-19, tata laksana, terapi

\section{Therapeutic Management of Patients with COVID-19: A Narrative Review}

\begin{abstract}
Pneumonia caused by severe acute respiratory syndrome coronavirus 2 (SARS-CoV-2) - named coronavirus diseases 2019 (COVID-19) by World Health Organization (WHO) - has been a global public health emergency. Timely and effective therapeutic strategies are of importance in saving patients' lives. However up to now, there is no specific treatment approved for COVID-19. This review aimed 1) to describe the available therapeutic strategies, and 2) to explore options of medications that can be used to treat COVID-19. A search strategy using keywords (("corona virus") OR ("covid-19") OR ("SARSCoV-2")) AND (("treatment") OR ("therapy")) was conducted in PubMed database. The review showed that treatment strategies could be different between settings and/or countries considering the availability of resources, particularly medications. The current WHO as well as the Indonesian guidelines mainly recommended supportive therapy to treat COVID-19, including: symptomatic care, oxygen therapy, antibiotics, fluid therapy, vasopressors, and taking medical interventions (including the use of ventilator). Studies conducted so far indicated the potential benefits of some medications, including chloroquine/ hydrochloroquine, arbidol, ribavirin, favipiravir, lopinavir/ritonavir, remdesivir, oseltamivir, and interferon; however, the evidences available have been limited and not strong enough to recommend any specific medication for COVID-19. While waiting for quality evidences, optimising the use of medications - reported to have some levels of effectiveness- could be the current best option to save patients, especially those who are critically ill.
\end{abstract}

Keywords: COVID, medication, therapeutic management

Korespondensi: apt. Eko Setiawan, S.Farm., M.Sc., Pusat Informasi Obat dan Layanan Kefarmasian (PIOLK), Fakultas Farmasi, Universitas Surabaya, Surabaya, Jawa Timur 60293, Indonesia, email: ekosetiawan.apt@gmail.com Naskah diterima: 24 Maret 2020, Diterima untuk diterbitkan: 30 Maret 2020, Diterbitkan: 31 Maret 2020 


\section{Pendahuluan}

Infeksi yang disebabkan oleh coronavirus jenis baru, yakni: severe acute respiratory syndrome coronavirus-2 (SARS-CoV-2), merupakan salah satu permasalahan kesehatan global. ${ }^{1,2}$ World Health Organisation (WHO) memberi nama atau identitas penyakit yang disebabkan SARS-CoV-2 sebagai coronavirus disease 2019 atau yang dikenal juga dengan istilah COVID-19. Proses transmisi antarmanusia yang cukup tinggi menyebabkan virus ini dengan cepat menyebar ke berbagai negara, termasuk Indonesia, dari yang pada mulanya menjadi wabah di Wuhan, Provinsi Hubei, China. ${ }^{1,3}$ Sampai saat ini, penularan SARSCoV-2 diyakini melalui droplets yang dikeluarkan ketika seseorang yang terinfeksi bersin atau batuk dan kontak. Droplets tersebut kemudian dapat terhirup secara langsung melalui saluran pernapasan atau masuk ke saluran napas melalui tangan yang terpapar virus karena menyentuh permukaan benda yang terdapat virus. ${ }^{3,4}$ Diperkirakan satu orang dapat menyebarkan virus kepada dua sampai tiga orang yang berarti SARS-CoV-2 lebih menular dibandingkan dengan infeksi coronavirus yang lain, yakni: Middle East Respiratory Syndrome coronavirus (MERS$\mathrm{CoV}) .{ }^{3}$ Selain itu, penting untuk diketahui bahwa seseorang yang sudah terpapar dengan coronavirus dapat tidak menunjukkan gejala apapun dan tetap dapat menularkan kepada orang lain. ${ }^{5}$ Setiap individu, termasuk yang merasa sehat, perlu semaksimal mungkin untuk menghindari pertemuan secara fisik, khususnya dalam skala besar, sebagai salah satu strategi memutus mata rantai penularan. Sampai dengan tanggal 28 Maret 2020, jumlah kasus positif COVID-19 di Indonesia adalah 1.155 pasien dan 102 dari antaranya mengalami kematian (case fatality ratel $\mathrm{CFR}=8,83 \%) .{ }^{6}$ Selama proses menunggu keberadaan vaksin yang efektif dan aman untuk COVID-19, ${ }^{6}$ berbagai upaya preventif perlu dilakukan untuk menekan penyebaran antara lain dengan menerapkan menjaga jarak aman antara satu orang dengan yang lain (physical distancing) dan isolasi diri maupun isolasi wilayah. ${ }^{2,8}$

Selain pencegahan, pemberian terapi pada mereka yang sudah dinyatakan positif terjangkit COVID-19 juga perlu diupayakan seoptimal mungkin dengan tujuan menekan angka CFR. Sampai saat ini, belum terdapat satu jenis obat yang telah mendapat izin edar untuk indikasi COVID-19. Oleh karena itu, berbagai jenis obat digunakan sebagai upaya untuk menyelamatkan nyawa pasien, khususnya mereka dengan tingkat keparahan tinggi. Dengan mempertimbangkan adanya kesamaan struktur gen dengan dua jenis coronavirus yang lain, yakni: severe acute respiratory syndrome coronavirus (SARSCoV-1) yang mewabah pada tahun 2003 dan MERS-CoV sebesar 79\% dan 50\% secara berturut-turut, ${ }^{9}$ maka terapi obat yang terbukti efektif atau menjanjikan digunakan untuk terapi infeksi SARS-CoV-1 dan MERS-CoV, saat ini, juga dieksplorasi efektivitasnya untuk terapi SARS-CoV-2. Artikel ini bertujuan untuk 1) memaparkan tata laksana pengobatan dan 2) mendaftar serta menjelaskan alternatif obat yang dapat digunakan untuk SARS$\mathrm{CoV}-2$. Sebagai catatan yang penting untuk digarisbawahi, dengan mempertimbangkan cepatnya tambahan informasi terkait terapi COVID-19, sangat dimungkinkan bahwa terdapat perubahan informasi dari apa yang disampaikan dalam artikel ini. Oleh sebab itu, pembaca diharapkan terus memperbaharui perkembangan terapi, yakni dengan cara membaca panduan terapi, khususnya yang disediakan oleh Kementerian Kesehatan Republik Indonesia, dan hasil penelitian (original article) terbaru. Informasi terkait pilihan terapi yang dapat digunakan untuk COVID-19 penting untuk diketahui pada situasi terjadinya pandemi sebagai antisipasi jika suatu titik, obat yang disarankan dalam 
pedoman terapi tidak tersedia di lapangan.

\section{Metode}

Metode penulisan artikel ini adalah kajian naratif (narrative review). Database utama pada proses penelusuran artikel dalam kajian pustaka ini adalah PubMed dengan kata kunci ((“corona virus") OR ("covid-19") OR ("SARS-CoV-2")) AND ((“treatment") OR ("therapy")). Semua artikel terpublikasi sampai tanggal 24 Maret 2020 berpotensi untuk dilibatkan dalam kajian literatur ini. Penelusuran pustaka yang digunakan sebagai referensi dalam artikel terpublikasi juga dilakukan sebagai upaya untuk memperkaya kajian ini. Penting untuk disampaikan bahwa kami mengupayakan untuk mendapatkan bukti penelitian dengan kualitas yang baik untuk mendukung kajian pustaka ini, yakni penelitian yang menggunakan desain acak terkontrol (randomised control trials; RCTs) untuk membuktikan efektivitas dan keamanan terapi. Namun demikian, keberadaan bukti penelitian berkualitas mungkin tidak selalu tersedia dalam literatur terpublikasi pada saat kondisi pandemi yang relatif baru terjadi. Oleh sebab itu, bukti penelitian klinis dengan berbagai desain dan juga penelitian nonklinis (baik pada hewan coba maupun in-vitro) diikutsertakan dalam kajian pustaka ini. Selain itu, berita terkait update terapi yang terdapat pada surat kabar tercetak maupun online, deskripsi penelitian yang didaftarkan pada lembaga pendaftaran uji klinis (clinical trial registry), dan abstrak yang tertulis dalam bahasa Inggris dari laporan penelitian berbagai negara juga digunakan sebagai acuan untuk memperkaya cakupan kajian pustaka ini.

\section{Pedoman Tata Laksana Pengobatan Pasien dengan COVID-19}

Pasien dengan COVID-19 memiliki beberapa gejala ringan yang menyerupai gejala flu seperti demam, batuk, sakit tenggorokan, produksi sputum, dan malaise. ${ }^{10,11}$ Namun demikian, peradangan pada parenkim paruparu akibat adanya infeksi patogen, atau dalam istilah medis dikenal sebagai pneumonia, dengan berbagai tingkat keparahan (ringan sampai berat), juga merupakan manifestasi klinis yang banyak dijumpai pada kasus infeksi COVID-19. ${ }^{12}$ Pada beberapa pasien, perburukan kondisi dapat terjadi dengan manifestasi klinis acute respiratory distress syndrome (ARDS), kegagalan pernapasan, dan kegagalan fungsi berbagai macam organ (multiple organ dysfunction). ${ }^{12,13}$ Walaupun jarang, keluhan pada sistem pencernaan seperti diare dan mual juga dapat terjadi pada pasien dengan COVID-19. ${ }^{14}$ Perburukan kondisi lebih cepat terjadi pada kelompok geriatrik, khususnya mereka yang berusia $\geq 65$ tahun dan memiliki komorbid penyakit menahun seperti diabetes melitus (DM) dan /atau hipertensi. ${ }^{15}$ Selain kelompok geriatrik, pasien anak-anak, khususnya bayi yang baru lahir (neonates), juga perlu mendapat perhatian dengan mempertimbangkan bahwa sistem kekebalan tubuh yang belum terbentuk sempurna. ${ }^{15,16}$ Sampai saat ini, diperkirakan 80\% kasus positif COVID-19 merupakan kasus infeksi yang relatif ringan atau bahkan tidak menunjukkan gejala sama sekali, 15\% adalah kasus infeksi parah yang membutuhkan terapi oksigen dan 5\% lainnya adalah kasus kritis yang membutuhkan ventilator. ${ }^{15}$

Pada bulan Maret 2020, WHO mengeluarkan pedoman tata laksana pengobatan untuk pasien dengan COVID-19. ${ }^{18}$ Pada kasus ringan, yang didefinisikan sebagai "pasien dengan infeksi saluran napas bagian atas tanpa komplikasi dengan gejala yang tidak spesifik, antara lain: demam, lemas, batuk (baik dengan maupun tanpa gejala), kehilangan nafsu makan, malaise, nyeri otot, sakit tenggorokan, sesak napas, hidung tersumbat, atau sakit kepala; dan kemungkinan disertai gejala yang jarang terjadi seperti diare, mual, atau muntah"; 
berikut merupakan tata laksana terapinya: (1) Terapi simptomatis, seperti: antipiretik untuk demam; (2) Edukasi pasien terkait perburukan gejala yang membutuhkan penanganan medis lebih lanjut; dan (3) Umumnya, pasien dengan tingkat keparahan ringan, tidak membutuhkan perawatan di rumah sakit. Perlu ditekankan bahwa pasien perlu melakukan isolasi diri sebagai upaya untuk meminimalkan sebaran virus. Tempat untuk melakukan isolasi sangat ditentukan oleh ketersediaan sumber daya setempat maupun negara. Walaupun dapat dilakukan di rumah, isolasi di rumah sakit perlu diupayakan pada setting dengan risiko terjadinya penularan secara sporadis.

Catatan diberikan untuk kelompok pasien geriatrik dan pasien dengan gangguan sistem kekebalan tubuh karena kedua kelompok tersebut dapat memiliki gejala atypical. Pada kondisi pandemik seperti saat ini, apoteker komunitas perlu segera merujuk pasien dengan gejala menyerupai ISPA, khususnya kelompok geriatrik dan pediatrik, ke dokter untuk mendapat pemeriksaan lebih lanjut terkait kemungkinan pemeriksaan COVID-19. Selain kedua kelompok tersebut, penanganan pasien dalam kondisi hamil perlu mendapat perhatian khusus karena beberapa gejala COVID-19 dapat serupa dengan gejala yang terjadi sebagai respon terhadap adaptasi fisiologis kondisi hamil: sesak napas, demam, dan gejala pada saluran cerna seperti mual. ${ }^{18}$

Pasien dewasa dengan tingkat keparahan tinggi sebagai akibat pneumonia, pneumonia berat, ARDS, sepsis, maupun syok sepsis membutuhkan perawatan di rumah sakit. Detail definisi untuk setiap manifestasi klinis, baik untuk dewasa maupun anak-anak, dapat dilihat pada pedoman terapi WHO.${ }^{18}$ Berikut adalah beberapa langkah tata laksana pasien COVID-19 dengan tingkat keparahan tinggi: ${ }^{18}$

Terapi oksigen

Terapi oksigen diperlukan terutama pada pasien-pasien yang mengalami severe acute respiratory infection (SARI) dan distress napas, hipoksemia, sentral sianosis, syok, koma atau konvulsi. Berikut adalah teknis pemberian terapi oksigen pada pasien dengan COVID-19: (a) Dewasa: berikan oksigen $5 \mathrm{~L} /$ menit selama proses resusitasi hingga mencapai target $\mathrm{SpO} 2 \geq 93 \%$ atau gunakan face mask dengan reservoir bag 10-15 L/ menit pada pasien kritis. Ketika pasien sudah stabil, target $\mathrm{SpO} 2$ adalah $>90 \%$ pada pasien yang tidak hamil dan $\geq 92-95 \%$ pada pasien hamil; (b) Anak-anak: berikan oksigen melalui nasal prongs atau nasal cannula dengan target $\mathrm{SpO} 2 \geq 94 \%$ selama proses resusitasi. Target $\mathrm{SpO} 2$ pada pasien anak yang stabil adalah $\geq 90 \%$; (c) Pantau kondisi pasien dengan COVID-19 secara ketat dan lakukan identifikasi gejala perburukan kondisi seperti terjadinya gagal napas dan sepsis. Berikan tindakan secepatnya untuk menyelamatkan nyawa pasien; (d) Perhatikan kondisi penyerta pasien, dan terapi COVID-19 tetap perlu memperhatikan kondisi penyerta tersebut.

\section{Terapi infeksi penyerta}

Terapi antibiotik empirik perlu diberikan segera untuk mengatasi patogen yang diduga menyebabkan SARI dan sepsis. Dengan mempertimbangkan bahwa: 1) pneumonia dengan berbagai tingkat keparahan merupakan manifestasi klinis yang sering menyebabkan kebutuhan perawatan di rumah sakit, dan 2) tidak semua rumah sakit memiliki pedoman tata laksana terapi pneumonia, maka dalam kajian pustaka ini turut disampaikan pilihan mengenai antibiotik yang direkomendasikan pada pedoman tata laksana pneumonia terbaru dari American Thoracic Society and Infectious Diseases Society of America (ATS-IDSA; Tabel 1). ${ }^{19}$

Pada kasus sepsis, antibiotik harus diberikan dalam satu jam pertama sejak proses awal identifikasi sepsis. ${ }^{20,21}$ Pemilihan antibiotik empirik harus mempertimbangkan diagnosis klinis, epidemiologi penyakit, data kepekaan 
Tabel 1 Pilihan Antibiotika untuk Terapi Pneumonia Komunitas Berdasarkan ATS/IDSA $2019^{19}$

\begin{tabular}{|c|c|c|c|c|c|c|}
\hline $\begin{array}{c}\text { Tempat } \\
\text { Perawatan }\end{array}$ & $\begin{array}{l}\text { Standar } \\
\text { Regimen }\end{array}$ & Dosis & $\begin{array}{c}\text { Memiliki Riwayat } \\
\text { Terinfeksi } \\
\text { MRSA } \\
\text { Sebelumnya }\end{array}$ & $\begin{array}{c}\text { Memiliki } \\
\text { Riwayat } \\
\text { Terinfeksi } \\
\text { Pseudomonas } \\
\text { aeruginosa } \\
\text { Sebelumnya }\end{array}$ & $\begin{array}{c}\text { Riwayat Dirawat di } \\
\text { Rumah Sakit dan } \\
\text { Memperoleh Antibiotik } \\
\text { Secara Parenteral dan } \\
\text { Ada Risiko Infeksi MRSA }\end{array}$ & $\begin{array}{c}\text { Riwayat Dirawat di Rumah } \\
\text { Sakit dan Memperoleh } \\
\text { Antibiotik Secara Parenteral } \\
\text { dan Ada Risiko Infeksi } \\
\text { Pseudomonas aeruginosa }\end{array}$ \\
\hline \multicolumn{7}{|l|}{ Rawat Jalan } \\
\hline $\begin{array}{l}\text { Tanpa } \\
\text { komorbid atau } \\
\text { faktor risiko } \\
\text { MRSA atau } \\
\text { Pseudomonas } \\
\text { aeruginosa* }\end{array}$ & $\begin{array}{l}\text { Amoksisilin, atau } \\
\text { Doksisiklin, atau } \\
\text { Makrolida (bila resistensi } \\
\text { pneumococcal lokal }<25 \% \text { ) }\end{array}$ & $\begin{array}{l}\text { Amoksisilin 3x1 gram } \\
\text { Doksisiklin 2x100 mg } \\
\text { Azithromisin } 500 \mathrm{mg} / \mathrm{hari} \\
\text { pertama dilanjutkan } 250 \mathrm{mg} \\
\text { Klaritromisin 2x500 mg }\end{array}$ & - & - & - & - \\
\hline $\begin{array}{l}\text { Dengan } \\
\text { komorbid }^{\ddagger}\end{array}$ & $\begin{array}{l}\text { 1. Terapi kombinasi: } \\
\text { amoksisilin/klavulanat } \\
\text { atau sefalosporin DAN } \\
\text { makrolida atau } \\
\text { doksisiklin } \\
\text { ATAU } \\
\text { 2. Monoterapi dengan } \\
\text { fluorokuinolon } \\
\text { respiratori }\end{array}$ & 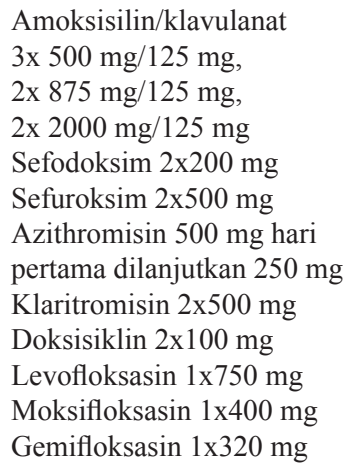 & - & - & - & - \\
\hline \multicolumn{7}{|l|}{ Rawat Inap } \\
\hline $\begin{array}{l}\text { Non severe } \\
\text { pneumonia }\end{array}$ & $\begin{array}{l}\text { Beta laktam + makrolida } \\
\text { ATAU } \\
\text { Beta laktam + Florokuinolon } \\
\text { respiratori }\end{array}$ & $\begin{array}{l}\text { Ampisilin/sulbaktam } \\
\text { 1,5-3 gram setiap } 6 \text { jam } \\
\text { Sefotaksim 3x 1-2 gram } \\
\text { Seftriakson 1-2 gram/hari } \\
\text { Seftarolin 2x600 mg } \\
\text { Azithromisin } 1 \times 500 \mathrm{mg} \\
\text { Klaritromisin } 2 \times 500 \mathrm{mg} \\
\text { Levofloksasin } 1 \times 750 \mathrm{mg} \\
\text { Moksifloksasin } 1 \times 400 \mathrm{mg}\end{array}$ & $\begin{array}{l}\text { Tambahkan } \\
\text { antibiotik yang } \\
\text { memiliki aktivitas } \\
\text { terhadap MRSA } \\
\text { dan lakukan kultur/ } \\
\text { nasal PCR sebagai } \\
\text { dasar deeskalasi } \\
\text { atau melanjutkan } \\
\text { terapi }\end{array}$ & $\begin{array}{l}\text { Tambahkan } \\
\text { antibiotik } \\
\text { yang memiliki } \\
\text { aktivitas } \\
\text { terhadap } \\
\text { Pseudomonas } \\
\text { aeruginosa dan } \\
\text { lakukan kultur } \\
\text { sebagai dasar } \\
\text { deeskalasi atau } \\
\text { melanjutkan } \\
\text { terapi }\end{array}$ & $\begin{array}{l}\text { Pemberian antibiotik yang } \\
\text { memiliki aktivitas terhadap } \\
\text { Pseudomonas aeruginosa } \\
\text { hanya ketika hasil kultur } \\
\text { menunjukkan positif } \\
\text { Tambahkan antibiotik yang } \\
\text { memiliki aktivitas terhadap } \\
\text { MRSA }{ }^{\mathrm{S}} \text { dan lakukan kultur/ } \\
\text { nasal PCR sebagai dasar } \\
\text { deeskalasi atau melanjutkan } \\
\text { terapi }\end{array}$ & $\begin{array}{l}\text { Pemberian antibiotik yang } \\
\text { memiliki aktivitas terhadap } \\
\text { Pseudomonas aeruginosa } \\
\text { hanya ketika hasil kultur } \\
\text { menunjukkan positif } \\
\text { Tambahkan antibiotik yang } \\
\text { memiliki aktivitas terhadap } \\
\text { Pseudomonas aeruginosa } \\
\text { dan lakukan kultur sebagai } \\
\text { dasar deeskalasi atau } \\
\text { melanjutkan terapi }\end{array}$ \\
\hline
\end{tabular}


kuman lokal rumah sakit, dan panduan terapi nasional.

Terapi acute respiratory distress syndrome (ARDS)

Detail teknis tindakan medis, termasuk tentang pengaturan ventilator dan pemasangan intubasi untuk menyelamatkan nyawa pasien, harus dilakukan oleh tenaga terlatih sesuai dengan pedoman terapi WHO. ${ }^{18}$ Terapi cairan yang disarankan untuk pasien tanpa hipoperfusi jaringan adalah pendekatan terapi cairan konservatif sesuai dengan protokol masingmasing rumah sakit.

Terapi kondisi kritis, khususnya syok sepsis Terapi standar yang perlu segera diberikan dalam waktu satu jam setelah diagnosis ditegakkan, termasuk pemberian antibiotik, terapi cairan, dan penggunaan vasopresor untuk mengatasi kondisi hipotensi dilakukan sesuai dengan pedoman tata laksana terapi untuk dewasa ${ }^{20}$ dan anak. ${ }^{21}$

Penggunaan kortikosteroid sebagai terapi penunjang

Penggunaan kortikosteroid sistemik secara rutin tidak direkomendasikan pada pasien dengan pneumonia yang disebabkan oleh virus, kecuali terdapat indikasi lain.

\section{Monitoring Kondisi Pasien Secara Ketat dan Berkesinambungan}

Di Indonesia, sampai dengan tulisan ini dibuat, terdapat 2 (dua) pedoman terapi untuk pasien dengan COVID-19, yakni pedoman yang dikeluarkan Direktorat Jenderal Pencegahan dan Pengendalian Penyakit, Kementerian Kesehatan Republik Indonesia edisi Maret $2020^{22}$ dan pedoman terapi oleh Perhimpunan Dokter Paru Indonesia (PDPI). ${ }^{23}$ Pada prinsipnya, tata laksana pasien COVID-19 yang dijelaskan dalam kedua pedoman terapi di Indonesia tersebut serupa dengan yang dinyatakan WHO dengan modifikasi sesuai kearifan dan ketersediaan sumber daya di Indonesia. Pedoman terapi yang dikeluarkan oleh Direktorat Jenderal Pencegahan dan Pengendalian Penyakit menyatakan secara jelas peran serta tanggung jawab seluruh pemangku kepentingan dalam penanganan wabah COVID-19 mulai dari pusat kesehatan masyarakat (puskesmas), fasilitas pelayanan kesehatan lain (rumah sakit dan klinik), rumah sakit rujukan, Dinas Kesehatan Kabupaten/ Kota, Dinas Kesehatan Provinsi, Kementerian Kesehatan Pusat. ${ }^{22}$ Dalam pedoman tersebut, dianjurkan agar pasien dalam pengawasan (PDP), yang definisinya dapat dilihat pada Tabel 2, dengan gejala sedang atau gejala ringan yang tidak memiliki fasilitas karantina rumah yang memadai perlu mendapatkan karantina dan tata laksana di fasilitas khusus atau rumah sakit darurat COVID-19.22 Selain itu, orang dalam pemantauan (ODP; Tabel 2) yang berusia di atas 60 tahun dengan penyakit penyerta terkontrol juga perlu mendapatkan tata laksana sesuai kondisi di fasilitas khusus atau rumah sakit darurat COVID-19.22 PDP dengan tingkat keparahan berat perlu untuk mendapatkan tata laksana di rumah sakit rujukan. Terkait dengan tata laksana infeksi penyerta, yakni pneumonia, PDPI juga merujuk pedoman terapi ATS-IDSA terbaru sebagaimana juga dipaparkan pada kajian pustaka kami. ${ }^{23}$ Baik WHO maupun pedoman di Indonesia, sampai tulisan ini dibuat, belum merekomendasikan secara spesifik obat untuk virus SARS-CoV-2. ${ }^{18,22,23}$ Namun demikian, terdapat beberapa negara yang memasukkan obat yang diduga efektif untuk SARS-CoV-2 sebagai bagian dari tata laksana terapi pasien dengan COVID-19 (Tabel 3). ${ }^{24-26}$

\section{Pilihan Obat yang Potensial Bermanfaat untuk SARS-CoV-2}

Klorokuin/Hidroksiklorokuin Klorokuin (N4-(7-Chloro-4-quinolinyl)-N1, 
Tabel 2 Kriteria Pasien dengan Pengawasan ${ }^{22}$

\begin{tabular}{|c|c|c|c|c|c|c|c|}
\hline & \multicolumn{4}{|c|}{ PDP* } & \multicolumn{3}{|c|}{ ODP** } \\
\hline & $\begin{array}{c}\text { Kriteria } \\
1\end{array}$ & $\begin{array}{c}\text { Kriteria } \\
2\end{array}$ & $\begin{array}{c}\text { Kriteria } \\
\mathbf{3}\end{array}$ & $\begin{array}{c}\text { Kriteria } \\
4\end{array}$ & $\begin{array}{c}\text { Kriteria } \\
1\end{array}$ & $\begin{array}{c}\text { Kriteria } \\
2\end{array}$ & $\begin{array}{c}\text { Kriteria } \\
\mathbf{3}\end{array}$ \\
\hline $\begin{array}{l}\text { Demam }\left(\geq 38^{\circ} \mathrm{C}\right) \text { atau } \\
\text { riwayat demam }\end{array}$ & Ya & $\mathrm{Ya}$ & & & $\mathrm{Ya}$ & & \\
\hline $\begin{array}{l}\text { ISPA; gejala/tanda, antara } \\
\text { lain: batuk/pilek/sakit } \\
\text { tenggorokan/sesak napas/ } \\
\text { pneumonia ringan hingga } \\
\text { berat }\end{array}$ & Ya & & $\mathrm{Ya}$ & & & & \\
\hline $\begin{array}{l}\text { Tidak ada penyebab lain } \\
\text { berdasarkan gambaran } \\
\text { klinis yang meyakinkan }\end{array}$ & $\mathrm{Ya}$ & & & $\mathrm{Ya}$ & $\mathrm{Ya}$ & Ya & \\
\hline $\begin{array}{l}\text { Memiliki riwayat } \\
\text { perjalanan atau tinggal di } \\
\text { luar negeri atau area di } \\
\text { Indonesia }{ }^{a} \text { yang melaporkan } \\
\text { tranmisi dalam } 14 \text { hari } \\
\text { terakhir sebelum timbul } \\
\text { gejala }\end{array}$ & Ya & & & & $\mathrm{Ya}$ & Ya & \\
\hline $\begin{array}{l}\text { Riwayat kontak dengan } \\
\text { kasus pasien confirm } \\
\text { COVID-19 dalam } 14 \text { hari } \\
\text { terakhir sebelum timbul } \\
\text { gejala }\end{array}$ & & $\mathrm{Ya}$ & $\mathrm{Ya}$ & & & & $\mathrm{Ya}$ \\
\hline $\begin{array}{l}\text { ISPA berat atau pneumonia } \\
\text { berat }{ }^{c} \text { hingga berat yang } \\
\text { membutuhkan perawatan di } \\
\text { rumah sakit }\end{array}$ & & & & Ya & & & \\
\hline $\begin{array}{l}\text { Gejala gangguan sistem } \\
\text { pernapasan seperti pilek/ } \\
\text { sakit tenggorokan/batuk }\end{array}$ & & & & & & Ya & Ya \\
\hline
\end{tabular}

\section{Keterangan:}

PDP=Pasien Dalam Pengawasan; ODP=Orang Dalam Pemantauan; *Seseorang diklasifikasikan sebagai PDP jika memenuhi salah satu dari kriteria berikut; ${ }^{* *}$ Seseorang diklasifikasikan sebagai ODP jika memenuhi salah satu dari kriteria berikut; ${ }^{\text {a Situs }}$ http://infeksiemerging.kemkes.go.id dapat digunakan untuk mengidentifikasi negara dan area di Indonesia dengan tranmisi COVID-19; 'Kasus confirm didefinisikan sebagai seseorang terinfeksi COVID-19 dengan hasil pemeriksaan laboratorium positif; 'Kriteria pasien dengan ISPA atau pneumonia berat: pasien remaja atau dewasa: demam atau dalam pengawasan infeksi saluran napas, ditambah satu dari: frekuensi napas $>30 \mathrm{x} /$ menit, distress pernapasan berat, atau saturasi oksigen $(\mathrm{SpO} 2)$ $<90 \%$ pada udara kamar; pasien anak: batuk atau kesulitan bernapas, ditambah setidaknya satu dari berikut ini: -sianosis sentral atau SpO2 <90\%; -distress pernapasan berat (seperti mendengkur, tarikan dinding dada yang berat); -tanda pneumonia berat: ketidakmampuan menyusui atau minum, letargi ataupenurunan kesadaran, atau kejang; -tanda lain dari pneumonia yaitu: tarikan dinding dada, takipnea: $<2$ bulan, $\geq 60 \mathrm{x} /$ menit; $2-11$ bulan, $\geq 50 \mathrm{x} /$ menit; $1-5$ tahun, $\geq 40 \mathrm{x} / \mathrm{menit} ;>5$ tahun, $\geq 30 \mathrm{x} / \mathrm{menit}$

N1-diethyl-1,4-pentanediamine), baik dalam bentuk garam fosfat maupun sulfat, telah sejak lama digunakan sebagai antimalaria. Obat tersebut merupakan bentuk amine acidotropic dari quinine yang pertama kali diproduksi pada tahun 1934 oleh Bayer di Jerman. ${ }^{27}$ Namun dalam kurun waktu beberapa tahun terakhir, klorokuin sudah sangat jarang digunakan.
Hal ini disebabkan perkembangan resistensi Plasmodium falciparum terhadap klorokuin yang telah meluas; selain itu, klorokuin yang digunakan secara tidak tepat, khususnya dosis berlebihan, dapat menyebabkan keracunan akut dan bahkan kematian. ${ }^{27}$

Kemudian pada tahun 1946, diperkenalkan hidroksiklorokuin yang merupakan derivatif 
Tabel 3 Pilihan Jenis Obat untuk Pasien Positif COVID-19 pada Beberapa Negara

\begin{tabular}{|c|c|c|}
\hline China $^{24}$ & Malaysia $^{25}$ & $\operatorname{Iran}^{26, *}$ \\
\hline \multirow{4}{*}{$\begin{array}{l}\text { Pilihan antivirus berikut dapat } \\
\text { digunakan: } \\
\text { Interferon- } \alpha \\
\text { Lopinavir/ritonavir } \\
\text { Ribavirin } \\
\text { Klorokuin fosfat } \\
\text { Arbidol }\end{array}$} & $\begin{array}{l}\text { Pasien tanpa pneumonia tetapi } \\
\text { menunjukkan gejala sakit: } \\
\text { hidroksiklorokuin atau klorokuin }\end{array}$ & $\begin{array}{l}\text { Pneumonia sedang sampai berat: } \\
\text { oseltamivir + hidroksiklorokuin } \\
\text { + lopinavir/ritonavir }\end{array}$ \\
\hline & $\begin{array}{l}\text { Pasien dengan pneumonia yang } \\
\text { menunjukkan gejala: } \\
\text { hidroksiklorokuin dan apabila } \\
\text { menunjukkan warning signs }{ }^{\text {b }} \text { : } \\
\text { tambahkan lopinavir/ritonavir }\end{array}$ & \multirow[t]{3}{*}{$\begin{array}{l}\text { Pneumonia ringan dengan } \\
\text { faktor risiko } \text { : oseltamivir }+ \\
\text { hidroksiklorokuin }\end{array}$} \\
\hline & $\begin{array}{l}\text { Pasien dengan pneumonia } \\
\text { yang menunjukkan gejala dan } \\
\text { membutuhkan terapi oksigen: } \\
\text { hidroksiklorokuin dan lopinavir/ } \\
\text { ritonavir }\end{array}$ & \\
\hline & $\begin{array}{l}\text { Pasien kritis: hidroksiklorokuin dan } \\
\text { lopinavir/ritonavir dan ribavirin } \\
\text { atau interferon beta }\end{array}$ & \\
\hline
\end{tabular}

Keterangan:

${ }^{a}$ Catatan diberikan: Pemilihan antivirus harus memperhatikan kondisi pasien dan profil reaksi obat yang tidak dikehendaki (ROTD), kontraindikasi, serta interaksi obat dengan terapi yang digunakan atau diberikan pasien. Tidak direkomendasikan untuk menggunakan tiga atau lebih antivirus pada saat yang bersamaan. Antivirus harus dihentikan penggunaannya apabila ROTD tidak dapat ditoleransi pasien; ${ }^{\mathrm{b}}$ Warning signs=demam, penurunan ALC, peningkatan CRP, takikardi; 'Faktor risiko: riwayat penggunaan obat untuk indikasi immunodeficiency atau immunosuppressive; riwayat sakit kronis antara lain: diabetes, gangguan fungsi ginjal, jantung, pernapasan, gangguan regulasi tekanan darah dan metabolik; "Pedoman terapi pada anak-anak

klorokuin-yakni dengan menambahkan gugus hidroksil pada klorokuin. Berdasarkan data pada hewan, ditemukan bahwa toksisitas hidroksiklorokuin lebih rendah dibandingkan dengan klorokuin $(\sim 40 \%) .{ }^{27}$ Sampai saat ini, hidroksiklorokuin masih banyak digunakan untuk terapi penyakit autoimun, seperti systemic lupus erythematosus dan rheumatoid arthritis. ${ }^{27} \mathrm{Di}$ tengah wabah novel coronavirus (SARS-CoV-2), klorokuin kembali mendapat perhatian karena beberapa publikasi terbaru menunjukkan potensi manfaat klorokuin untuk terapi COVID-19. ${ }^{27-29}$

Mekanisme kerja klorokuin secara molekuler belum dapat dipahami dengan jelas. Berdasarkan hasil penelitian terdahulu, klorokuin dan hidroksiklorokuin diduga dapat menghambat coronavirus dengan melalui serangkaian mekanisme. Pertama, baik klorokuin maupun hidroksiklorokuin dapat mengubah $\mathrm{pH}$ pada permukaan membran sel sehingga dapat menghambat bersatunya ('fusion') virus tersebut dengan membran sel, dan imunomodulasi pelepasan sitokin. ${ }^{28-31}$ Kedua, klorokuin dapat menghambat quinone reductase 2 yang memiliki peran penting dalam pembentukan asam sialic; asam tersebut ditemukan pada protein sel transmembran yang merupakan komponen penting ikatan virus dan reseptor. ${ }^{27}$ Ketiga, klorokuin dapat menghambat proses glikosilasi protein virus dan sekaligus juga dapat memengaruhi proses glikosilasi reseptor angiotensin-converting enzyme 2 (ACE2) yang diduga merupakan mediator masuknya virus. ${ }^{28-31}$

Wang et al. (2020) melakukan uji invitro terhadap beberapa obat untuk melawan SARS-CoV-2, termasuk klorokuin. Hasil dari penelitian tersebut menunjukkan bahwa klorokuin berfungsi pada tahap entry maupun post-entry infeksi SARS-CoV-2 pada sel Vero E6. ${ }^{28}$ Aktivitas antivirus klorokuin-yang ditunjukkan dengan $50 \%$ maximal effective concentration $\left(\mathrm{EC}_{50}\right)$ - untuk melawan SARSCoV-2 pada sel Vero E6 cells adalah sebesar $1,13 \mu \mathrm{M}$. Selain $\mathrm{EC}_{50}$, penelitian tersebut juga 
melaporkan nilai beberapa parameter antara lain: cytotoxic concentration 50\% $\left(\mathrm{CC}_{50}\right)$ $\geq 100 \mathrm{Mm}$; selectivity index $(\mathrm{SI})=88,50$; dan $\mathrm{EC}_{90}=6,90 \mu \mathrm{M} \cdot{ }^{28} \quad \mathrm{EC}_{50}$ merupakan suatu parameter yang digunakan untuk mengamati potensi suatu obat untuk indikasi tertentu, dalam hal ini adalah konsentrasi obat yang dapat menghasilkan 50\% hambatan replikasi virus. ${ }^{32}$ Pada umumnya, selain melaporkan nilai $\mathrm{EC}_{50}$, suatu penelitian in-vitro juga akan melaporkan nilai inhibitory concentration $50 \%\left(\mathrm{IC}_{50}\right)$, nilai cytotoxic concentration $50 \%\left(\mathrm{CC}_{50}\right)$, dan nilai selectivity index $(\mathrm{SI})$. Nilai $\mathrm{IC}_{50}$ mengindikasikan besar konsentrasi suatu obat, dalam hal ini adalah antivirus, yang dibutuhkan untuk mengurangi sebanyak $50 \%$ dari jumlah sel yang terinfeksi virus. Sebaliknya, nilai $\mathrm{CC}_{50}$ menggambarkan besar konsentrasi obat yang telah terbukti dapat "membunuh" atau "menghancurkan" setengah dari sel yang tidak terinfeksi. ${ }^{32}$ Terakhir, nilai SI menggambarkan rasio antara nilai aktivitas antivirus (AVA value) terhadap nilai sitotoksisitas (TOX value) suatu obat. Nilai SI yang lebih tinggi, secara teori, mengindikasikan penggunaan suatu obat semakin efektif dan aman untuk suatu infeksi virus tertentu. ${ }^{32}$ Nilai $\mathrm{EC}_{90}$ klorokuin yang dibutuhkan untuk SARS-CoV-2 diperkirakan dapat dicapai dengan pemberian klorokuin $500 \mathrm{mg}$ sebagaimana diberikan untuk pasien dengan rheumatoid artritis. ${ }^{33}$

Penelitian selanjutnya oleh Liu et al. (2020) membandingkan aktivitas antivirus klorokuin versus hidroksiklorokuin terhadap SARS-CoV-2. Kurva dosis-respons kedua obat tersebut ditentukan dengan menggunakan empat multiplicities of infection (MOIs) yang berbeda $(0,01 ; 0,02 ; 0,2$ dan 0,8$) ; \mathrm{EC}_{50}$ klorokuin $(2,71 ; 3.81 ; 7,14$; dan $7,36 \mu \mathrm{M})$ lebih rendah dibandingkan hidroksiklorokuin $(4,51 ; 4,06$; 17,31; dan 12,96 $\mu \mathrm{M})$. Data ini menunjukkan bahwa hidroksiklorokuin tampaknya memiliki aktivitas anti- SARS-CoV-2 yang lebih rendah dibandingkan dengan klorokuin. ${ }^{34}$ Namun, penelitian Yao et al. (2020) menunjukkan bahwa hidroksiklorokuin $\left(\mathrm{EC}_{50}=0,72 \mu \mathrm{M}\right)$ terlihat lebih poten dibandingkan klorokuin $\left(\mathrm{EC}_{50}=5,47 \mu \mathrm{M}\right) .{ }^{29}$ Penyebab dari perbedaan hasil antara kedua penelitian tersebut tidak diketahui secara pasti. Terlepas dari perbedaan hasil yang ditemukan pada kedua penelitian tersebut, secara in-vitro, klorokuin maupun hidroksiklorokuin memiliki aktivitas antiSARS-CoV-2 yang baik.

Menindaklanjuti hasil penelitian in-vitro yang terlihat menjanjikan ini, setidaknya sebanyak 15 studi klinis telah dilakukan di lebih dari 10 rumah sakit di China. Laporan Gao et al. (2020) menyatakan bahwa sampai saat ini, hasil yang diperoleh dari lebih dari 100 pasien menunjukkan bahwa klorokuin terlihat superior dibandingkan dengan terapi kontrol dalam hal menurunkan eksaserbasi pneumonia, durasi gejala, dan penundaan klirens virus, serta tidak menunjukkan efek samping yang berbahaya. ${ }^{35}$ Akan tetapi, pernyataan ini perlu diinterpretasikan secara hati-hati karena tidak disertai data pendukung yang lebih detil. Lebih lanjut, suatu penelitian berskala kecil dengan desain nonrandom yang dilakukan Gautret et al. (2020) di Perancis $(\mathrm{n}=36)$ menunjukkan bahwa pasien yang mendapatkan hidroksiklorokuin mengalami penurunan jumlah virus (viral load) yang signifikan dibandingkan kelompok kontrol (pemeriksaan PCR negatif pada hari ke-6: 70\% versus $12,5 \%$, secara berurutan; $p=0,001) .{ }^{36}$ Selain itu, penambahan azithromisin dapat meningkatkan eliminasi virus dibandingkan pemberian hidroksiklorokuin tunggal atau kontrol (pemeriksaan PCR negatif pada hari ke-6: $100 \%$ versus $57,1 \%$ versus $12,5 \%$, secara berurutan; $p<0,001) .{ }^{36}$ Namun, penelitian yang dilakukan di China (Chen et al., 2020) pada 6-25 Februari 2020-melibatkan 30 pasien COVID-19 yang dirandomisasi untuk mendapatkan hidroksiklorokuin versus terapi konvensional - tidak menunjukkan adanya perbedaan yang signifikan terkait eliminasi 
virus (throat swab negatif pada hari ke-7: $86,7 \%$ versus $93,3 \%$, secara berurutan; $p>0,05$ ) (berdasarkan abstrak; artikel dalam bahasa China). ${ }^{37}$

Klorokuin maupun hidroksiklorokuin per oral dilaporkan memiliki absorpsi yang sangat baik pada manusia. ${ }^{27}$ Penelitian pada hewan menunjukkan bahwa kedua obat tersebut memiliki pola distribusi yang mirip; konsentrasi yang tinggi dijumpai di hati, limpa, ginjal dan paru-paru - dapat mencapai 200700 kali lebih tinggi dibandingkan dengan konsentrasi di dalam plasma. ${ }^{38}$ Konsensus para ahli di China merekomendasikan dosis klorokuin yang digunakan adalah $500 \mathrm{mg}$ dua kali sehari selama 10 hari pada pasien dewasa dengan COVID-19 pneumonia ringan, sedang maupun berat. ${ }^{39,40}$ Dosis hidroksiklorokuin yang digunakan dalam penelitian Gautret et al. (2020) adalah $200 \mathrm{mg} 3$ kali per hari selama 10 hari; ${ }^{36}$ dan pada penelitian Chen et al. (2020) digunakan dosis $400 \mathrm{mg}$ per hari selama 5 hari. ${ }^{37}$ Data terdahulu menunjukkan bahwa dosis normal hidroksiklorokuin sulfat (6-6,5 mg/kg per hari) dapat menghasilkan konsentrasi serum $1,4-1,5 \mu \mathrm{M}$ pada manusia, ${ }^{41}$ sehingga dalam rentang dosis yang aman, kemungkinan konsentrasi hidroksiklorokuin yang diharapkan untuk menghambat infeksi COVID-19 dapat dicapai (berdasarkan data in-vitro $^{34}$ ). Penelitian lebih lanjut masih diperlukan untuk memastikan dosis optimal klorokuin dan hidroksiklorokuin untuk terapi COVID-19.

Meskipun klorokuin dan hidroksiklorokuin menunjukkan efektivitas yang menjanjikan untuk terapi COVID-19, terutama berdasarkan uji in-vitro, bukti klinis yang ada masih sangat terbatas. Dari sisi keamanan, bukti yang ada menunjukkan bahwa klorokuin dan hidroksiklorokuin memiliki profil keamanan yang cukup baik. Namun demikian, perlu diketahui bahwa klorokuin memiliki rentang yang relatif sempit antara dosis terapeutik dan toksik; toksisitas klorokuin dilaporkan terkait dengan gangguan kardiovaskular yang membahayakan jiwa. ${ }^{27}$ Oleh karenanya, penggunaan klorokuin dan hidroksiklorokuin harus sesuai pedoman dan perlu pemantauan kondisi pasien yang ketat. Mempertimbangkan aspek keselamatan pasien, maka pengobatan sendiri tanpa resep tidak direkomendasikan. Hasil penelitian klinis dengan desain yang lebih baik masih ditunggu dan diperlukan untuk memastikan efektivitas (termasuk dosis optimal) dan keamanannya sebagai terapi COVID-19.

\section{Arbidol}

Arbidol merupakan salah satu antivirus dengan spektrum luas yang banyak digunakan khususnya di Rusia dan China untuk indikasi anti-influenza dan stimulasi imunitas (immune stimulating effect). ${ }^{42}$ Cakupan antivirus arbidol meliputi: virus influenza, respiratory syncytial virus, parainfluenza virus, rhinovirus 14, hepatitis B dan C, virus coxsackie. Arbidol bekerja dengan cara menghambat masuknya virus pada sel target, memblok ikatan antara virus dengan membran sel, dan menghambat proses replikasi virus. ${ }^{42-44}$

Bukti penelitian mengenai penggunaan arbidol untuk terapi infeksi COVID-19 masih terbatas. Hasil dari suatu penelitian in-vitro menunjukkan bahwa konsentrasi arbidol yang dibutuhkan untuk menghambat SARSCoV-2 adalah 10-30 $\mu \mathrm{M} .{ }^{45}$ Terdapat dua penelitian klinis terkait penggunaan arbidol yang dikombinasikan dengan antivirus lain untuk pasien dengan COVID-19. Penelitian Deng et al. (2020) yang melibatkan sebanyak 33 pasien COVID-19 menunjukkan bahwa kombinasi arbidol dengan lopinavir/ritonavir memberikan hasil yang lebih baik apabila dibandingkan lopinavir/ritonavir saja dalam hal konversi negatif deteksi virus corona (pada hari ke-7 dan 14), dan menunjukkan perbaikan kondisi pada hasil CT scan dada. ${ }^{46}$ Persentase pasien dengan konversi negatif pada grup kombinasi arbidol-lopinavir/ritonavir apabila 
dibandingkan dengan lopinavir/ritonavir pada hari ke-7 dan 14 secara berturut-turut adalah $75 \%$ versus $35 \%$ dan $94 \%$ versus $52,9 \%(\mathrm{p}<0,05)$. Persentase pasien dengan perbaikan hasil CT scan paru pada kelompok kombinasi dan monoterapi adalah $69 \%$ versus $29 \%(\mathrm{p}<0,05) .{ }^{46}$ Hasil penelitian lain oleh Wang et al. (2020) yang melibatkan empat kasus pasien COVID-19 di Shanghai, China, juga menunjukkan adanya perbaikan kondisi pasien yang diberi terapi kombinasi arbidol dengan lopinavir/ritonavir. ${ }^{47}$ Sebagai catatan, pada penelitian yang dilakukan oleh Wang et al. (2020), pasien juga diberikan terapi antibiotik dan obat tradisional China, serta kondisi awal pasien pada masing-masing kasus sedikit berbeda dengan rentang kasus infeksi ringan sampai berat. ${ }^{47}$ Walaupun arbidol memiliki potensi untuk digunakan dalam terapi COVID-19, namun diperlukan penelitian dengan desain acak terkontrol yang melibatkan jumlah sampel yang lebih besar untuk melihat efektivitas terapi, baik sebagai monoterapi atau kombinasi dengan antivirus yang lain.

Sebagai antivirus yang berpotensi untuk digunakan pada pandemi COVID-19, arbidol terdistribusi dengan cepat dalam jaringan dan organ pada saat 20 menit setelah pemberian secara oral. Besar akumulasi maksimum pada berbagai organ adalah sebagai berikut: di liver (3,1\%/g jaringan), kelenjar pituitari $(1,7 \%)$, ginjal $(1,2 \%)$, nodus limfatik $(1,2 \%)$, dan tiroid, kelenjar adrenal, sumsum tulang belakang, paru-paru, plasma, thymus, serta limpa $(<1 \%)$. Sebesar $40 \%$ dari total arbidol akan diekskresikan 48 jam dalam bentuk tidak berubah (unchanged), terutama di feses $(38,9 \%)$ dan sedikit di urin $(0,12 \%))^{42,46}$ Secara umum, arbidol dapat ditoleransi dengan baik pada manusia. ${ }^{42}$ Dosis arbidol yang direkomendasikan sebagai terapi COVID-19 secara oral adalah 200 mg 3 kali sehari dengan durasi terapi tidak lebih dari 10 hari. ${ }^{40,46,47}$

\section{Ribavirin}

Ribavirin merupakan analog nukleosida dengan aktivitas antivirus spektrum luas. ${ }^{50-52}$ Ribavirin memiliki kemampuan melawan virus dengan mekanisme yang berbeda-beda, dan memiliki mekanisme kerja baik secara langsung dan tidak langsung pada virus. Mekanisme antivirus secara langsung terjadi dengan cara: 1) memengaruhi proses RNA capping yang diperlukan untuk stabilitas RNA dan proses translasi dari virus, dan 2) menghambat polimerase RNA virus. Adapun mekanisme secara tidak langsung terjadi melalui proses: 1) penghambatan inosine monophosphate (IMP) dehydrogenase yang dapat menghambat proses replikasi virus dan juga 2) efek imunomodulator dengan mempertahankan respon imun dari T-helper tipe $1 .{ }^{49-51}$

Terdapat penelitian in-vitro yang dilakukan oleh Wang et al. (2020) untuk mengidentifikasi potensi penggunaan ribavirin untuk mengatasi infeksi SARS-CoV-2. ${ }^{28}$ Hasil dari penelitian tersebut menunjukkan nilai $\mathrm{EC}_{50}, \mathrm{CC}_{50}$, dan SI ribavirin untuk mengatasi sel kultur terinfeksi SARS-CoV-2 adalah 109,50 $\mu \mathrm{M},>400 \mu \mathrm{M}$, dan $>3,65$, secara berturut-turut. ${ }^{28}$ Dari hasil tersebut, dapat diketahui bahwa konsentrasi yang dibutuhkan untuk melakukan hambatan replikasi virus lebih rendah dibandingkan dengan konsentrasi menghancurkan sel yang tidak terinfeksi. Dengan kata lain, ribavirin adalah kandidat yang baik untuk dieksplorasi efektivitasnya secara klinis.

Sampai saat ini, bukti penelitian klinis terkait penggunaan ribavirin sebagai terapi infeksi COVID-19 masih terbatas. Terdapat beberapa penelitian penggunaan efektivitas dan keamanan kombinasi ribavirin dengan beberapa jenis obat yang lain, antara lain: IFN- $\alpha$, lopinavir/ritonavir dan IFN- $\alpha$, yang saat ini masih berjalan. ${ }^{54}$ Dengan demikian, pengalaman penggunaan obat ini pada kasus infeksi coronavirus yang lain diperlukan sebagai data awal kemungkinan menggunakan 
obat ini untuk COVID-19. Data penelitian yang ditemukan untuk indikasi SARS-CoV-1 menunjukkan bahwa kombinasi ribavirin dan lopinavir/ritonavir dapat mengurangi risiko terjadinya ARDS dibandingkan penggunaan ribavirin monoterapi $(2,4 \%$ versus $28,8 \%$, $\mathrm{p}<0,001) .{ }^{52}$ Dalam sebuah kajian sistematis yang relatif baru dipublikasikan, terdapat bukti penelitian studi kasus dan observasional mengenai penggunaan kombinasi ribavirin dengan IFN- $\alpha$ untuk pasien dengan infeksi MERS- CoV. ${ }^{53}$

Ribavirin termasuk salah satu terapi yang direkomendasikan untuk infeksi COVID-19 menurut pedoman terapi yang dikeluarkan oleh National Health Commission (NHC) pemerintah China. Metode administrasi yang direkomendasikan adalah pemberian infus intravena dengan dosis $500 \mathrm{mg}$ setiap kali pemberian dan diberikan 2-3 kali sehari. ${ }^{40}$ Pemberian tersebut perlu dikombinasikan dengan IFN- $\alpha$ atau lopinavir/ritonavir dengan durasi pemberian tidak lebih dari 10 hari. ${ }^{40}$ Reaksi obat yang tidak dikehendaki dari ribavirin seperti anemia hemolitik, gangguan elektrolit, serta gangguan fungsi hati dan ginjal. Oleh karenanya, diperlukan pemantauan hasil laboratorium terhadap total dan differential blood cell count, serum laktat dehidrogenase, elektrolit, aspartate transaminase/AST, alanine transaminase/ALT, dan bilirubin tiap dua hari sekali. ${ }^{55}$

\section{Favipiravir}

Favipiravir, atau yang juga dikenal dengan nama favilavir atau avigan, merupakan suatu antivirus yang dikembangkan oleh Toyama Chemical di Jepang untuk berbagai strain virus influenza. ${ }^{56,57}$ Favipiravir merupakan pro-drug yang akan dimetabolisme dalam tubuh menjadi zat aktif, yakni: favipiravir-ribofuranosyl-5'triphosphate (favipiravir-RTP). ${ }^{56}$ Pada tahun 2014, favipiravir disetujui penggunaannya di Jepang sebagai terapi novel atau re-emerging virus influenza dan, pada dasarnya, ditujukan sebagai persiapan apabila terjadi pandemi influenza. ${ }^{57}$ Saat kajian ini ditulis, favipiravir merupakan obat pertama yang disetujui oleh pemerintah China sebagai terapi COVID-19 di China. ${ }^{58}$ Favipiravir bekerja sebagai penghambat selektif RNA-dependent RNA polymerase ( $\mathrm{RdRp}$ ), yang merupakan salah satu enzim yang digunakan untuk transkripsi dan replikasi genom RNA virus. ${ }^{56,40}$ Dengan demikian, favipiravir memiliki potensi untuk menghambat replikasi dari berbagai jenis virus RNA, dan dapat dikatakan memiliki potensi sebagai antivirus dengan spektrum luas. $^{56}$

Secara in-vitro, favipiravir efektif untuk virus influenza tipe $\mathrm{A}, \mathrm{B}$, dan $\mathrm{C} .{ }^{56}$ Hasil penelitian in-vitro tersebut ditegaskan oleh hasil penelitian pada hewan yang terinfeksi virus influenza yang menunjukkan bahwa favipiravir dapat meningkatkan survival rate dan menurunkan jumlah virus (viral load). Selain influenza, favipiravir efektif terhadap virus berbagai jenis virus RNA termasuk arenaviridae, bunyaviridae, flaviviridae, picornaviridae, caliciviridae, rhabdoviridae, dan filoviridae. ${ }^{56}$ Beberapa penelitian pada hewan coba juga menunjukkan efektivitas favipiravir dalam hal menurunkan jumlah virus atau meningkatkan survival rate hewan coba yang diinfeksi oleh virus west nile, virus yellow fever, virus chikunguya, virus rabies, dan sebagainya. ${ }^{57}$ Penelitian in-vitro oleh Wang et al. (2020) menunjukkan potensi penggunaan favipiravir untuk menghambat replikasi SARS-CoV-2. ${ }^{28}$ Nilai $\mathrm{EC}_{50}, \mathrm{CC}_{50}$, dan SI favipiravir untuk mengatasi sel kultur yang terinfeksi SARS-CoV-2 adalah $61,88 \mu \mathrm{M}$, $>400 \mu \mathrm{M}$, dan $>6,46$, secara berturut-turut. ${ }^{28}$

Penelitian klinis nonacak pada manusia menunjukkan bahwa favipiravir juga pernah digunakan sebagai terapi pasien yang terinfeksi ebola, dan disebutkan bahwa favipiravir dapat menurunkan jumlah virus dan meningkatkan survival pada pasien dengan viremia rendah atau sedang..$^{57,59,60}$ Saat ini, penelitian klinis 
untuk membuktikan efektivitas favipiravir pada pasien COVID-19 sedang berjalan di China. ${ }^{61}$ Salah satu penelitian yang dilakukan oleh Cai et al. di Shenzhen, China pada 80 orang pasien positif COVID-19 menunjukkan bahwa favipiravir memiliki profil efektivitas yang superior dan efek samping yang lebih rendah dibandingkan lopinavir/ritonavir. ${ }^{61,62}$ Penelitian tersebut menggunakan desain open label non randomised control trial, dengan 35 pasien berada pada kelompok favipiravir dan 45 pasien pada kelompok lopinavir/ritonavir. Dosis favipiravir yang diberikan adalah $1.600 \mathrm{mg}$ dua kali sehari pada hari pertama dilanjutkan $600 \mathrm{mg}$ dua kali sehari pada hari ke-2 sampai ke-14. Dosis lopinavir/ritonavir yang diberikan adalah $400 \mathrm{mg}$ lopinavir/100 mg ritonavir pada hari ke-1 sampai ke-14. Hasil penelitian menunjukkan tidak terdapat perbedaan yang signifikan pada karakteristik awal pasien. Pasien pada kelompok fapiviravir mengalami klirens virus yang lebih rendah secara signifikan dibandingkan kelompok lopinavir/ritonavir (median empat hari versus 11 hari, secara berurutan; $p<0,001)$. Selain itu, hasil penelitian menunjukkan terdapat perbedaan bermakna pada perbaikan hasil CT scan dada (perbaikan CT scan dada pada hari ke-14: 91\% versus 62\%, secara berurutan; $\mathrm{p}<0,004)$. Total kejadian efek samping pada kelompok fapiravir juga lebih rendah dibanding kelompok lopinavir/ritonavir (11\% versus $56 \%$, secara berurutan; $p<0,001)$. Di samping limitasi desain penelitiannya, studi pendahuluan ini mengindikasikan bahwa fapiviravir memberikan hasil yang lebih baik untuk terapi COVID-19 dalam hal mencegah progresivitas penyakit maupun klirens virus dibandingkan lopinavir/ritonavir.

Selain penelitian tersebut, terdapat penelitian lain yang dilakukan oleh Chen et al. (2020) di tiga rumah sakit di provinsi Hubei, China. ${ }^{63}$ Sebanyak 240 pasien direkrut sebagai subjek penelitian, dengan 120 pasien berada pada grup fapiviravir (116 yang dianalisis) dan 120 pasien pada grup arbidol (120 yang dianalisis). Rejimen dosis yang digunakan pada penelitian tersebut adalah: 1) favipiravir: $1.600 \mathrm{mg}$ dua kali sehari pada hari pertama dilanjutkan $600 \mathrm{mg}$ dua kali sehari mulai hari kedua sampai terapi dihentikan; arbidol: 200 mg tiga kali sehari sejak hari pertama sampai terapi dihentikan. Pada 116 pasien di grup favipiravir, 98 pasien dikategorikan sebagai pasien dengan tingkat keparahan "ordinary" dan 18 sisanya dikategorikan sebagai "critical". Sebanyak 42 pasien dari 116 pasien pada kelompok favipiravir mempunyai hipertensi dan/atau diabetes. Dari 120 pasien di grup arbidol, 111 pasien dikategorikan "ordinary" dan 9 pasien dikategorikan "critical"; 35 pasien dari 120 pasien ini merupakan pasien hipertensi dan/atau diabetes. Perbaikan klinis setelah tujuh hari penggunaan antivirus pada kedua grup ini tidak berbeda secara signifikan, yaitu: $61 \%$ pada grup fapiviravir dan $52 \%$ pada grup arbidol $(\mathrm{p}=0,14)$. Akan tetapi, apabila analisis dilakukan hanya pada grup pasien "ordinary", terdapat perbedaan yang signifikan terkait perbaikan klinis dalam tujuh hari, yaitu: $71 \%$ pasien pada grup fapiviravir dibandingkan dengan $56 \%$ pasien pada grup arbidol $(\mathrm{p}=0,02)$. Pada pasien dengan hipertensi dan/atau diabetes, waktu terjadinya penurunan demam dan sembuhnya batuk pada grup fapiviravir lebih pendek dibandingkan grup arbidol ( $p<0,0001)$, akan tetapi tidak terdapat perbedaan bermakna pada auxiliary oxygen therapy atau non-invasive mechanical ventilation rate. Peningkatan nilai serum asam urat lebih sering terjadi pada grup fapiravir dibandingkan arbidol (16 kasus versus tiga kasus, secara berurutan; $\mathrm{p}=0,0014)$. Chen et al. menyimpulkan untuk pasien kategori "ordinary", fapiviravir dapat dipertimbangkan sebagai terapi pilihan COVID-19. Limitasi utama pada penelitian tersebut adalah ketidakseimbangan proporsi pasien dengan kategori "critical" antara dua grup, sehingga hal ini dapat memengaruhi 
hasil penelitian. Hal lain yang penting untuk menjadi pertimbangan adalah, saat penulisan kajian ini, penelitian oleh Chen et al. tersebut merupakan draft hasil penelitian yang masih perlu melalui proses kajian oleh ahli (peer review). ${ }^{61,63}$

Dengan demikian, apabila favipiravir hendak digunakan, dapat dipertimbangkan untuk memberikan dosis $1.600 \mathrm{mg} 2 \mathrm{kali}$ sehari di hari pertama dilanjutkan $600 \mathrm{mg}$ 2 kali sehari untuk hari berikutnya. Durasi pemberian favipiravir yang ditemukan dalam penelitian terpublikasi adalah 14 hari, namun keputusan terkait lama penggunaan obat ditentukan oleh dokter sesuai dengan penilaian kondisi klinis masing-masing pasien. Selain itu, penggunaan favipiravir tidak dianjurkan pada wanita hamil karena bersifat teratogenik dan embryotoxic. ${ }^{56}$

\section{Lopinavir/Ritonavir}

Lopinavir/ritonavir merupakan antivirus yang bekerja dengan cara menghambat protease (protease inhibitor) dan digunakan pada pasienpasien yang terinfeksi human immunodeficiency virus selama ini. Lopinavir terbukti memiliki mekanisme menghambat kerja enzim 3CL protease (atau disebut juga dengan 3CLpro atau Mpro) dan papain-like protease PLpro yang berperan penting pada proses replikasi coronavirus ${ }^{64}$ Ritonavir merupakan penghambat sitokrom P-450 yang jika digunakan bersama lopinavir akan menyebabkan peningkatan bioavailabilitas lopinavir. ${ }^{65}$

Hasil penelitian in-vitro oleh Chu et al. (2004) menunjukkan bahwa penggunaan lopinavir/ritonavir bersama dengan ribavirin menunjukkan efek sinergistik terhadap SARSCoV-1. ${ }^{52}$ Penelitian tersebut juga menyatakan, penambahan ribavirin akan meningkatkan potensi lopinavir sebanyak empat kali lipat. Selain itu, melalui penelitian tersebut dapat diketahui konsentrasi yang dibutuhkan untuk menghasilkan efek antivirus terhadap SARSCoV-1 adalah $4 \mu \mathrm{g} / \mathrm{mL}$.
Penelitian klinis pada manusia yang terinfeksi coronavirus dapat disebut sebagai salah satu inspirasi penggunaan lopinavir/ ritonavir untuk kasus COVID-19. Chu et al. (2004) meneliti efek dari lopinavir/ritonavir secara klinis pada 41 pasien yang terinfeksi SARS-CoV-1. ${ }^{52}$ Hasil penelitian tersebut menunjukkan bahwa penggunaan lopinavir/ ritonavir yang dikombinasi dengan ribavirin efektif menurunkan kematian dan kejadian ARDS dibandingkan dengan periode ketika pengobatan dilakukan tanpa menggunakan obat tersebut, yakni 2,4\% dibandingkan dengan $28,8 \%$, secara berturut-turut $(\mathrm{p}<0,001)$. Pada kasus infeksi coronavirus yang lain, yakni MERS-CoV, ditemukan bahwa kombinasi lopinavir/ritonavir dengan ribavirin sebagai intervensi post-exposure prophylaxis pada tenaga kerja yang merawat pasien terpapar MERS-CoV terbukti efektif menurunkan risiko terjadinya infeksi. ${ }^{66}$

Terdapat bukti penelitian terkait dengan penggunaan lopinavir/ritonavir pada kasus COVID-19 di berbagai negara. Pertama, sebuah laporan studi kasus di Korea Selatan yang menunjukkan efektivitas penggunaan lopinavir/ritonavir pada pasien usia 54 tahun. Dosis yang digunakan pada kasus tersebut adalah lopinavir $400 \mathrm{mg} /$ ritonavir $100 \mathrm{mg}$ yang diberikan selama dua kali sehari. Pada akhir terapi, didapatkan bahwa viral load $\beta$-coronavirus menurun secara bermakna dan hampir tidak ditemukan titer coronavirus pada pasien ${ }^{67}$ Kedua, sebuah penelitian yang dilakukan di Singapura pada lima pasien yang membutuhkan terapi oksigen. ${ }^{68}$ Hasil yang diperoleh pada terapi penelitian tersebut bervariasi antarpasien. Kebutuhan oksigen pada tiga dari lima pasien yang mendapat lopinavir/ritonavir mengalami penurunan pada hari ke-3 terapi yang mengindikasikan adanya perbaikan pernapasan pasien. Selain itu, tidak ditemukan virus pada hapusan nasofaring pada dua dari lima pasien. Namun di samping hasil positif tersebut, sebanyak 
dua dari lima pasien mengalami perburukan kondisi walaupun telah diberikan lopinavir/ ritonavir. Satu orang pasien membutuhkan ventilator dan hasil hapusan nasofaring atau selang endotrakeal pada dua pasien tersebut tetap menunjukkan adanya virus. Terlepas dari perbedaan hasil pada kedua penelitian tersebut, perlu dicatat bahwa dosis yang digunakan pada pasien di Singapura tersebut adalah lopinavir $200 \mathrm{mg} /$ ritonavir $100 \mathrm{mg}$ yang diberikan sebanyak dua kali sehari yang mana lebih rendah dari dosis pada laporan kasus di Korea Selatan. ${ }^{67,68}$

Penelitian ketiga, yang merupakan penelitian dengan desain penelitian terbaik sampai saat ini, berasal dari China. Penelitian dengan desain penelitian acak terkontrol tersebut dilakukan pada sebanyak 199 pasien COVID-19 dengan saturasi oksigen $\leq 94 \%$ atau rasio partial pressure of oxygen $(\mathrm{PaO} 2)$ terhadap fraction inspired oxygen (FiO2) $<300$ mmHg. ${ }^{69}$ Dosis yang digunakan pada penelitian tersebut adalah lopinavir $400 \mathrm{mg}$ / ritonavir $100 \mathrm{mg}$ dua kali sehari. Secara umum, hasil penelitian tersebut menunjukkan tidak terdapat perbedaan yang bermakna dibandingkan dengan terapi standar dalam hal waktu yang dibutuhkan untuk mencapai perbaikan kondisi klinis (HR 1,24; 95\%; CI 0,90-1,72). Hasil analisis modified intentionto-treat analysis menunjukkan bahwa waktu yang dibutuhkan untuk mencapai perbaikan kondisi pada kelompok yang mendapatkan terapi lopinavir/ritonavir lebih cepat satu hari dibandingkan pada kelompok yang mendapat terapi standar (HR 1,39; 95\% CI 1,00-1,91). Perlu didiskusikan dengan klinisi mengenai apakah perbedaan satu hari tersebut dapat dipertimbangkan sebagai angka bermakna secara klinis atau tidak. Parameter kedua yang diamati pada penelitian di China tersebut adalah perbedaan angka kematian. Angka kematian pada hari ke-28 pada kelompok yang mendapatkan lopinavir/ritonavir dan terapi standar adalah: 19,2\% versus $25,0 \%$ secara berturut-turut (perbedaan -5.8; 95\% CI -17,3-5,7). Walaupun perbedaan tersebut tidak bermakna secara signifikan, namun angka kematian pada kelompok yang mendapatkan lopinavir/ritonavir tetap lebih rendah jika dibandingkan dengan kelompok terapi standar. Efek samping yang paling banyak terjadi pada pasien dengan lopinavir/ ritonavir adalah efek samping pada saluran cerna. Salah satu faktor penyebab lopinavir/ ritonavir tidak memberikan efektivitas yang baik pada penelitian di China tersebut adalah penggunaan obat tersebut pada pasien dengan late infection dan jumlah virus yang cukup tinggi yang mana pada kondisi tersebut diduga sudah terjadi kerusakan organ (khususnya paru-paru) yang cukup besar. Selain itu, terdapat dugaan bahwa konsentrasi lopinavir/ ritonavir dalam tubuh pasien tidak mencapai konsentrasi yang cukup untuk menghambat replikasi virus sebagaimana ditemukan pada penelitian in-vitro. ${ }^{70}$

Beberapa pedoman tata laksana di beberapa negara dengan kasus COVID-19 mencantumkan lopinavir/ritonavir sebagai salah satu pilihan terapi. ${ }^{24-26}$ Di Korea Selatan, pasien geriatrik atau pasien yang memiliki penyakit penyerta dengan kondisi infeksi parah perlu diberikan terapi untuk mengatasi replikasi virus dan salah satu pilihan terapinya adalah lopinavir $400 \mathrm{mg} /$ ritonavir $100 \mathrm{mg}$ sebanyak dua kali sehari. ${ }^{71}$ Metode administrasi obat ini adalah secara per-oral dan dapat diberikan sampai dengan 10 hari. $^{40}$

\section{Remdesivir}

Remdesivir, sebuah antivirus yang dibuat oleh Gilead Sciences, memiliki aktivitas terhadap berbagai jenis virus termasuk MERS-CoV dan SARS-CoV-1..$^{40,72}$ Remdesivir merupakan suatu phosphoramidate prodrug, yang di dalam tubuh akan termetabolisme menjadi C-adenosine nucleoside analogue GS-441524 sebagai metabolit aktifnya. ${ }^{73,74}$ Mekanisme kerja remdesivir terutama terkait dengan 
replikasi virus. ${ }^{73}$ Remdesivir merupakan analog nukleosida adenosine yang akan mengganggu kerja RNA polymerase dari virus dan selanjutnya menurunkan kemampuan replikasi virus. ${ }^{73}$ Disebabkan oleh kemiripan remdesivir dengan adenosine, salah satu nukleotida untuk pembentukan RNA, maka dapat memungkinkan RNA polymerase salah mengenali remdesivir sebagai adenosine. Penempatan analog adenosine ini lalu akan mengakhiri proses transkripsi, yang akhirnya menyebabkan virus tidak dapat bereplikasi atau menginfeksi sel yang lain. ${ }^{75,76}$

Remdesivir merupakan obat yang pada mulanya dikembangkan untuk terapi virus ebola, yang lalu dicobakan juga terhadap coronavirus seperti MERS-CoV dan SARS$\mathrm{CoV}-1 .{ }^{75}$ Pada penelitian hewan coba dengan SARS-CoV-1, pemberian remdesivir di saat awal terjadinya infeksi dapat menurunkan jumlah virus pada sel paru tikus, serta dapat memperbaiki tanda-tanda klinis dan fungsi paru. ${ }^{72}$ Hasil penelitian pada hewan coba dengan infeksi MERS-CoV menunjukkan adanya efektivitas remdesivir yang lebih baik dibandingkan kombinasi lopinavir/ritonavir dan IFN- $\beta$. Perbaikan fungsi paru, penurunan jumlah virus, dan perbaikan pengamatan patologi paru terjadi pada hewan coba yang mendapatkan terapi remdesivir, baik untuk tujuan profilaksis maupun terapi. Pada hewan coba yang mendapatkan lopinavir/ritonavir yang dikombinasikan dengan IFN- $\beta$, terdapat perbaikan namun tidak terjadi pada semua parameter. ${ }^{72}$ Hasil yang tampak menjanjikan untuk coronavirus jenis lain ini lalu memicu penelitian remdesivir untuk SARS-CoV-2. Penelitian in-vitro oleh Wang et al. (2020) mengungkapkan bahwa remdesivir dapat menghambat infeksi SARS-CoV-2 dalam konsentrasi molekuler rendah dan memiliki SI yang tinggi. ${ }^{28}$ Potensi aktivitas antivirus remdesivir diamati pada $\mathrm{EC}_{50}=0,77 \mu \mathrm{M} ; \mathrm{CC}_{50}$ $>100 \mu \mathrm{M}$; SI > 129,87). ${ }^{28}$

Penelitian untuk membuktikan efektivitas penggunaan antivirus remdesivir pada pasien COVID-19 saat ini sedang berjalan, dan diperkirakan baru akan selesai di akhir April 2020. ${ }^{40}$ Namun, terdapat sebuah laporan kasus yang melaporkan tentang adanya efektivitas penggunaan remdesivir pada pasien yang terinfeksi COVID-19 di Amerika Serikat. ${ }^{77}$ Pasien pada laporan kasus tersebut berusia 35 tahun dan memiliki riwayat perjalan ke Wuhan, China. Setelah mendapatkan hasil CT scan dada yang menunjukkan adanya pneumonia dan pasien mengalami penurunan saturasi $\mathrm{O}_{2}$ menjadi $90 \%$, pasien diberikan kombinasi vankomisin dan cefepim karena terpikir tentang kemungkinan adanya hospital acquired pneumoniae. Dengan memperhatikan bahwa tidak terdapat perbaikan CT scan dada, remdesivir mulai diberikan pada pasien dan keesokan harinya ditemukan perbaikan kondisi klinis. Saat ini, masih terlalu dini untuk menyimpulkan efektivitas penggunaan remdesivir untuk pasien dengan COVID-19. Namun demikian, pada situasi yang belum terdapat satu pun jenis obat yang disetujui penggunaannya pada pasien COVID-19, penggunaan remdesivir dapat menjadi sebuah alternatif terapi dengan mempertibangkan hasil uji in-vitro yang menjanjikan. ${ }^{28}$

Sambil menunggu hasil dari penelitian klinis selesai dan dipublikasikan, saat ini dapat dipertimbangkan untuk memberikan remdesivir dengan dosis $200 \mathrm{mg}$ pada hari pertama pemberian dan dosis $100 \mathrm{mg}$ yang dapat diberikan mulai dari hari ke-2 sampai ke-9 untuk pasien dengan tingkat keparahan sedang sampai parah. ${ }^{78,79}$ Sebagai catatan, pemberian remdesivir dapat dipertimbangkan hanya sampai pada hari ke-5 pada pasien dengan tingkat keparahan sedang. ${ }^{78}$ Selain itu, apabila diputuskan untuk menggunakan remdesivir, waktu untuk mulai memberikan obat ini perlu diperhatikan karena pemberian remdesivir pada pasien tertentu tidak berdampak pada perbaikan fungsi paru walaupun dapat menurunkan jumlah virus. ${ }^{80}$ Sampai saat ini 
belum banyak negara yang menggunakan obat ini. Hal ini dapat disebabkan obat ini merupakan obat yang masih berada dalam tahap uji coba (experimental drugs) dan belum diproduksi untuk dipasarkan secara luas - saat ini obat ini didapatkan atas dasar compassionate use dari Gilead Sciences atau untuk pasien yang masuk dalam penelitian klinis.

\section{Oseltamivir}

Oseltamivir merupakan bagian dari golongan neuraminidase inhibitors (NAIs) yang mempunyai mekanisme kerja dengan cara menghambat neuraminidase virus ${ }^{81}$ Dampak dari hambatan tersebut adalah menghambat pelepasan partikel virus dari sel yang terinfeksi sehingga mengurangi penyebaran virus pada saluran napas.

Awal penggunaan oseltamivir sebagai terapi pasien COVID-19 dimulai pada sebuah rumah sakit di Wuhan, China, yakni Wuhan Jinyintan Hospital. ${ }^{14}$ Hasil pengamatan secara retrospektif terhadap 99 pasien menunjukkan sebanyak 75 pasien mendapatkan berbagai terapi antivirus, dan salah satu antivirus yang digunakan adalah oseltamivir dengan dosis $75 \mathrm{mg}$ setiap 12 jam secara oral. Durasi pemberian antivirus pada artikel terpublikasi tersebut adalah selama 3-14 hari (median 3 hari [IQR 3-6]). ${ }^{14}$ Selain antivirus, sebagian besar pasien (70\%) juga mendapat antibiotik baik dalam bentuk tunggal maupun kombinasi dengan durasi pemberian yakni selama 3-17 hari (median 5 hari [IQR 3-7]). Sebagian kecil dari pasien (19\%) mendapatkan terapi kortikosteroid selama 3-15 hari (median 5 hari [3-7]). Sebanyak 11 dari total 99 pasien (11\%) meninggal, 31 pasien (31\%) sembuh, dan sisanya masih mendapat perawatan di rumah sakit. Tidak terdapat simpulan terkait efektivitas penggunaan oseltamivir pada penelitian tersebut. ${ }^{14}$ Penelitian retrospektif lain terkait penggunaan oseltamivir yang dilakukan di Wuhan melibatkan 138 pasien
COVID-19 yang mendapat perawatan medis di Zhongnan Hospital of Wuhan University. ${ }^{13}$ Sebanyak 124 pasien $(89,9 \%)$ mendapat terapi oseltamivir dengan dosis yang bervariasi tergantung pada keparahan kondisi pasien. Sayangnya, detail informasi terkait dosis, frekuensi, dan durasi pemberian tidak dapat diketahui pada artikel penelitian tersebut. ${ }^{13}$ Sampai dengan akhir pengamatan, terdapat 6 kasus kematian (4,3\%), 47 pasien $(34,1 \%)$ diizinkan keluar rumah sakit, dan 85 yang lain $(61,6 \%)$ masih mendapat perawatan di rumah sakit. Seperti halnya dengan penelitian retrospektif pertama, tidak memungkinkan untuk membuat simpulan terkait efektivitas oseltamivir pada pasien dengan COVID-19. Selain di China, oseltamivir yang diberikan secara oral juga merupakan salah satu jenis obat yang digunakan dalam terapi pasien COVID-19 di Singapura. ${ }^{71}$ Namun demikian, informasi lebih lanjut terkait dosis dan durasi pemberian oseltamivir tidak dapat ditemukan pada penelitian tersebut. Sebuah studi kasus pada seorang pasien berusia 52 tahun di Taiwan juga menunjukkan penggunaan oseltamivir untuk COVID-19. Oseltamivir diberikan sejak hari pertama mendapatkan perawatan di rumah sakit yang dikombinasikan dengan penggunaan levofloksasin. ${ }^{82}$ Detail regimen dosis juga tidak ditampilkan pada laporan kasus tersebut. Setelah lebih kurang 14 hari menggunakan oseltamivir, pasien masih mendapat perawatan di rumah sakit dengan kondisi klinis dan tanda-tanda vital yang relatif stabil. Pasien tidak lagi membutuhkan oksigen untuk menunjang pernapasan yang mengindikasikan adanya perbaikan kondisi pernapasan.

Saat ini, terdapat dua penelitian klinis yang sedang berjalan untuk membuktikan efektivitas penggunaan oseltamivir pada pasien dengan COVID-19. ${ }^{83}$ Penelitian yang pertama dilakukan di China (Tongji Hospital) terhadap 400 pasien terinfeksi SARS-CoV-2 yang mendapat terapi arbidol atau lopinavir/ 
ritonavir atau oseltamivir dan diharapkan selesai pada bulan Juli 2020 (NCT04255017). Penelitian kedua di Thailand, yakni Rajavithi Hospital, dilakukan terhadap 80 pasien dengan COVID-19 dan diharapkan selesai pada bulan November 2020. Pada penelitian tersebut, oseltamivir dikombinasikan dengan favipiravir dan klorokuin.

\section{Interferon}

Secara umum, interferon (IFN) dapat diklasifikasikan menjadi dua tipe, yaitu: tipe I (IFN- $\alpha$ dan IFN- $\beta$ ) dan tipe II (IFN- $\gamma$ ). Interferon tipe I dihasilkan oleh sebagian besar sel di dalam tubuh, sedangkan interferon tipe II dihasilkan oleh sel natural killer dan sel limfosit $\mathrm{T}$ yang teraktivasi oleh virus. ${ }^{84,85}$ Pada infeksi SARS-CoV-1 dan MERS-CoV, aktivitas IFN ini disupresi oleh virus dengan berbagai mekanisme. Beberapa penelitian menemukan cara virus mensupresi aktivitas IFN dengan beberapa cara, yaitu: a) protein open reading frames (ORF) 6 yang dimiliki oleh SARS-CoV-1 memblok ekspresi gen STAT1 sehingga bersifat antagonis terhadap IFN $;{ }^{86}$ b) protein ORF4b memblok IRF3 dan IRF7 sehingga bersifat antagonis terhadap IFN- $\beta{ }^{87}$ c) SARS-CoV-1 dan MERS-CoV mampu menghasilkan enzim papain-like protease (PLP) yang dapat melemahkan sistem imun ${ }^{88}$ dan d) interaksi antara $\mathrm{CoV}$ dengan IFN-stimulated gen 15 (ISG12) dan bersifat antagonis terhadap IFN. ${ }^{89}$ Mekanisme spesifik yang berkaitan dengan IFN pada SARS-CoV-2 belum diketahui, namun dengan mempertimbangkan kesamaan struktur dan nukleotida penyusun dengan SARS-CoV, maka diduga mekanisme supresi aktivitas IFN juga serupa. Pemberian interferon eksternal diharapkan dapat meningkatkan jumlah interferon di dalam tubuh sehingga dapat menginduksi sintesis beberapa protein yang menghambat replikasi virus dan mengaktivasi sistem imun adaptif untuk dapat melawan virus.
Penelitian in-vitro pada sel Vero E6 yang diinfeksi dengan SARS-CoV (yang diisolasi dari Singapura dengan kode 2003VA2774) menunjukkan hasil bahwa interferon $\beta-1 b$ (Betaferon), interferon $\alpha-n 3$, interferon $\alpha-n 1$, dan leukocyte interferon $\alpha$ (Multiferon) dapat menghambat SARS-CoV pada konsentrasi $5000 \mathrm{IU} / \mathrm{mL}, 5000 \mathrm{IU} / \mathrm{mL}, 250.000 \mathrm{IU} / \mathrm{mL}$, dan $500.000 \mathrm{IU} / \mathrm{mL}$, secara berturut-turut. ${ }^{90}$ Terdapat beberapa penelitian klinis pada pasien dengan COVID-19 di China yang saat ini masih berlangsung dan melibatkan interferon sebagai salah satu regimen terapi. ${ }^{83}$ Penelitian pertama yang dilakukan di Beijing 302 Hospital melibatkan 150 pasien COVID-19 dengan regimen terapi obat tradisional China yang dikombinasi dengan lopinavir/ritonavir dan interferon- $\alpha$ secara inhalasi (NCT04251871). Penelitian tersebut diharapkan selesai pada bulan Januari 2021. Penelitian yang kedua bertujuan untuk melihat efektivitas recombinant human interferon $\alpha 2 \beta$ terhadap 328 pasien COVID-19 di Tongji Hospital (NCT04293887). Penelitian tersebut diharapkan dapat selesai pada bulan Juni 2020. Penelitian yang ketiga melibatkan kombinasi interferon secara inhalasi dengan lopinavir/ritonavir atau xiyanping pada 384 pasien COVID-19 (NCT04275388). Penelitian tersebut diharapkan dapat selesai pada bulan Desember 2020.

Sambil menunggu hasil dari penelitian klinis tersebut di atas, penggunaan interferon sebagai pilihan untuk terapi COVID-19 dapat dipertimbangkan khususnya jika pilihan terapi lain tidak mampu mengatasi kondisi pasien. Di Korea Selatan, penggunaan interferon direkomendasikan ketika lopinavir/ritonavir atau klorokuin atau hydroksiklorokuin tidak efektif atau tidak memungkinkan diberikan kepada pasien. ${ }^{71}$ Apabila digunakan, metode administrasi yang direkomendasikan untuk interferon- $\alpha$ yaitu secara inhalasi dengan dosis untuk pasien dewasa adalah 5 juta unit (dalam $2 \mathrm{~mL}$ air steril untuk injeksi) dan diberikan 
2 kali sehari. Durasi pemberian yang sesuai rekomendasi adalah tidak lebih dari 10 hari. ${ }^{40}$

\section{Simpulan}

Tata laksana pasien dengan COVID-19 dapat berbeda-beda antar-setting dan negara dengan mempertimbangkan ketersediaan sumber daya, khususnya obat. Sampai dengan tulisan ini dibuat, belum terdapat obat khusus yang direkomendasikan untuk menekan replikasi SARS-CoV-2 meskipun berdasarkan data hasil penelitian in-vitro yang tersedia, urutan Selectivity Index (SI) dari yang paling kuat adalah remdesivir (SI>129,87), klorokuin $(\mathrm{SI}=88,50)$, favipiravir $(\mathrm{SI}>6,46)$, dan ribavirin (SI>3,65). Selain itu, sampai dengan tulisan ini dibuat, terdapat keterbatasan bukti penelitian dengan desain yang baik (randomised controlled trial; RCT) yang dapat digunakan untuk menarik simpulan terkait superioritas suatu jenis obat tertentu dibandingkan alternatif yang lain. Beberapa jenis obat untuk menekan replikasi virus yang penggunaannya direkomendasikan di China, Malaysia, Iran, dan Korea Selatan adalah klorokuin atau hidroksiklorokuin atau lopinavir/ritonavir. Favipiravir saat ini menjadi pilihan terapi pasien COVID-19 di Jepang [based on personal communication with pharmacist from Japan]. Oseltamivir, ribavirin, dan interferon dapat dikombinasikan dengan ketiga jenis obat yang penggunaannya banyak direkomendasikan tersebut di atas, khususnya pada pasien dengan kondisi yang parah.

\section{Pendanaan}

Penelitian ini tidak didanai oleh sumber hibah manapun.

\section{Konflik Kepentingan}

Seluruh penulis menyatakan tidak terdapat potensi konflik kepentingan dengan penelitian, kepenulisan (authorship), dan atau publikasi artikel ini.

\section{Daftar Pustaka}

1. Rothan HA, Byrareddy SN. The epidemiology and pathogenesis of coronavirus disease (COVID-19) outbreak J Autoimmun. 2020;109:102433. doi: 10. 1016/j.jaut.2020.102433

2. Sohrabi C, Alsafi Z, O’Neill N, Khan M, Kerwan A, Al-Jabir A, et al. World Health Organization declares global emergency: A review of the 2019 novel coronavirus (COVID-19). Int J Surg. 2020;76:71-6. doi: 10.1016/j.ijsu.2020.02.034

3. Prompetchara E, Ketloy C, Palaga T. Immune responses in COVID-19 and potential vaccines: Lessons learned from SARS and MERS epidemic. Asian Pac J Allergy Immunol. 2020;38(1):1-9. doi: 10.12932/AP-200220-0772.

4. Li Q, Guan X, Wu P, Wang X, Zhou L, Tong Y, et al. Early transmission dynamics in Wuhan, China, of novel coronavirusinfected pneumonia. N Engl J Med. 2020; 382:1199-207. doi: 10.1056/NEJMoa200 1316

5. Biscayart C, Angeleri P, Lloveras S, Chaves TdSS, Schlagenhauf P, RodriguezMorales AJ. The next big threat to global health? 2019 novel coronavirus (2019$\mathrm{nCoV})$ : What advice can we give to travellers?-Interim recommendations January 2020, from the Latin-American Society for Travel Medicine (SLAMVI). Travel Med Infect Dis. 2020;33:101567. doi: 10.1016/j.tmaid.2020.101567.

6. Public Health Emergency Operating Center (PHEOC)-Kementerian Kesehatan Republik Indonesia. Covid-19: Situasi kasus Indonesia [Diakses pada: 29 Maret 2020]. Tersedia dari: https://infeksieme rging.kemkes.go.id/ 
7. Ahmed SF, Quadeer AA, McKay MR. Preliminary identification of potential vaccine targets for the COVID-19 Coronavirus (SARS-CoV-2) based on SARS-CoV immunological studies. Viruses. 2020;12(3):254. doi: 10.3390/v12030254

8. Bedford J, Enria D, Giesecke J, Heymann DL, Ihekweazu C, Kobinger G, et al. COVID-19: Towards controlling of a pandemic. Lancet. 2020;395(10229):1015 -8. doi: 10.1016/S0140-6736(20)30673-5

9. Lu R, Zhao X, Li J, Niu P, Yang B, Wu $\mathrm{H}$, et al. Genomic characterisation and epidemiology of 2019 novel coronavirus: implications for virus origins and receptor binding. Lancet. 2020;395(10224):56574. doi: 10.1016/S0140-6736(20)30251-8

10. Kannan S, Ali PSS, Sheeza A, Hemalatha K. COVID-19 (Novel Coronavirus 2019)Recent trends. Eur Rev Med Pharmacol Sci. 2020;24(4):2006-11. doi: 10.26355/ eurrev 202002 20378

11. Guan WJ, Ni ZY, Hu Y, Liang WH, Ou CQ, He JX, et al. Clinical characteristics of coronavirus disease 2019 in China. N Engl J Med. 2020;382:1708-20. doi: 10.1056/NEJMoa2002032

12. Huang C, Wang Y, Li X, Ren L, Zhao J, $\mathrm{Hu} \mathrm{Y}$, et al. Clinical features of patients infected with 2019 novel coronavirus in Wuhan, China. Lancet. 2020;395(10223): 497-506. doi: 10.1016/S0140-6736(20)3 0183-5

13. Wang D, Hu B, Hu C, Zhu F, Liu X, Zhang J, et al. Clinical characteristics of 138 hospitalized patients with 2019 novel coronavirus-infected pneumonia in Wuhan, China. J Am Med Assoc. 2020; 323(11):1061-9. doi: 10.1001/jama.2020. 1585

14. Chen N, Zhou M, Dong X, Qu J, Gong F, Han Y, et al. Epidemiological and clinical characteristics of 99 cases of 2019 novel coronavirus pneumonia in Wuhan, China: A descriptive study. Lancet. 2020;395
(10223):507-13. doi: 10.1016/S0140-67 36(20)30211-7

15. Yang X, Yu Y, Xu J, Shu H, Xia J, Liu $\mathrm{H}$, et al. Clinical course and outcomes of critically ill patients with SARS-CoV-2 pneumonia in Wuhan, China: A singlecentered, retrospective, observational study. Lancet Respir Med. 2020;8(5):475-81. doi: 10.1016/S2213-2600(20)30079-5

16. Kunz R, Minder M. COVID-19 pandemic: Palliative care for elderly and frail patients at home and in residential and nursing homes. Swiss Med Wkly. 2020;150:w20235. doi: 10.4414/smw.202 0.20235

17. World Health Organization. Coronavirus disease 2019 (COVID-19): Situation report -46. 2020 [Diakses pada: 28 Maret 2020]. Available from: https://www.who.int/doc $\mathrm{s} /$ default-source/coronaviruse/situationreports/20200306-sitrep-46-covid-19.pdf ?sfvrsn=96b04adf 2

18. World Health Organization. Clinical management of severe acute respiratory infection (SARI) when COVID-19 disease is suspected. 2020 [Diakses pada: 28 Maret 2020]. Tersedia dari: https:// www.who.int/publications-detail/clinical -management-of-severe-acute-respirator $\mathrm{y}$-infection-when-novel-coronavirus-(nc ov)-infection-is-suspected

19. Metlay JP, Waterer GW, Long AC, Anzueto A, Brozek J, Crothers K, et al. Diagnosis and treatment of adults with community-acquired pneumonia. An official clinical practice guideline of the American Thoracic Society and Infectious Diseases Society of America. Am J Respir Crit Care Med. 2019;200(7):e45-67. doi: 10.1164/rccm.201908-1581ST

20. Rhodes A, Evans LE, Alhazzani W, Levy MM, Antonelli M, Ferrer R, et al. Surviving sepsis campaign: International guidelines for management of sepsis and septic shock: 2016. Intensive Care Med. 
2017;43(3):304-77. doi: 10.1007/s00134 -017-4683-6

21. Weiss SL, Peters MJ, Alhazzani W, Agus MSD, Flori HR, Inwald DP, et al. Surviving sepsis campaign international guidelines for the management of septic shock and sepsis-associated organ dysfunction in children. Pediatr Crit Care Med. 2020;21(2):e52-106. doi: 10.1097/ PCC. 0000000000002198

22. Direktorat Jenderal Pencegahan dan Pengendalian Penyakit-Kementerian Kesehatan Republik Indonesia. Pedoman pencegahan dan pengendalian coronavirus disease (COVID-19) Jakarta: Kementerian Kesehatan Republik Indonesia; Maret 2020.

23. Perhimpunan Dokter Paru Indonesia. Pneumonia COVID-19: Diagnosis \& penatalaksanaan di Indonesia. Jakarta: Perhimpunan Dokter Paru Indonesia; 2020.

24. China Health Commission. Chinese clinical guidance for COVID-19 pneumonia diagnosis and treatment ( $7^{\text {th }}$ edition). 2020 [Diakses pada: 29 Maret 2020]. Available from: http://kjfy.meetingchina.org/msite/ news/show/cn/3337.html

25. Kementerian Kesihatan Malaysia. Garis panduan pengurusan COVID-19 di Malaysia No 5/2020: Clinical management of confirmed case. 2020 [Diakses pada: 29 Maret 2020]. Available from: http://www. moh.gov.my/moh/resources/Penerbitan/ Garis\%20Panduan/COVID19/Annex_2e Clinical_Management_22032020.pdf

26. Karimi A, Tabatabaei SR, Rajabnejad M, Pourghaddas Z, Rahimi H, Armin S, et al. An algorithmic approach to diagnosis and treatment of coronavirus disease 2019 (COVID-19) in children: Iranian Expert's Consensus Statement. Arch Pediatr Infect Dis. 2020;8(2):e102400. doi: 10.5812/pe dinfect. 102400

27. Devaux CA, Rolain JM, Colson P, Raoult D. New insights on the antiviral effects of chloroquine against coronavirus: What to expect for COVID-19?. Int J Antimicrob Agents. 2020;55(5):105938. doi: 10.1016/j. ijantimicag.2020.1059368

28. Wang M, Cao R, Zhang L, Yang X, Liu J, $\mathrm{Xu} \mathrm{M}$, et al. Remdesivir and chloroquine effectively inhibit the recently emerged novel coronavirus (2019-nCoV) in vitro. Cell Res. 2020;30(3):269-71. doi: 10.103 8/s41422-020-0282-0

29. Yao X, Ye F, Zhang M, Cui C, Huang B, Niu $P$, et al. In vitro antiviral activity and projection of optimized dosing design of hydroxychloroquine for the treatment of Severe Acute Respiratory Syndrome Coronavirus 2 (SARS-CoV-2). Clin Infect Dis. 2020; ciaa237. doi: 10.1093/cid/ciaa2 37

30. Ben-Zvi I, Kivity S, Langevitz P, Shoenfeld Y. Hydroxychloroquine: From malaria to autoimmunity. Clin Rev Allergy Immunol. 2012;42(2):145-53. doi: 10.1007/s12016010-8243-X

31. Cortegiani A, Ingoglia G, Ippolito M, Giarratano A, Einav S. A systematic review on the efficacy and safety of chloroquine for the treatment of COVID-19. J Crit Care. 2020;57:279-83. doi: 10.1016/j.jcr c.2020.03.005

32. Pritchett JC, Naesens L, Montoya J. Chapter 19: Treating HHV-6 infections: The laboratory efficacy and clinical use of anti-HHV-6 agents. In: Flamand L, Krueger GRF, Lautenschlager I, Ablashi DV. Human Herpesviruses HHV-6A, HHV-6B \& HHV-7: Diagnosis and clinical management. $3^{\text {rd }}$ edition. Amsterdam: Elsevier; 2014.

33. Mackenzie AH. Dose refinements in long-term therapy of rheumatoid arthritis with antimalarials. Am J Med. 1983;75 (1A):40-5. doi: 10.1016/0002-9343(83)9 1269-X

34. Liu J, Cao R, Xu M, Wang X, Zhang $\mathrm{H}, \mathrm{Hu} \mathrm{H}$, et al. Hydroxychloroquine, 
a less toxic derivative of chloroquine, is effective in inhibiting SARS-CoV-2 infection in vitro. Cell Discov. 2020;6:16. doi: 10.1038/s41421-020-0156-0

35. Gao J, Tian Z, Yang X. Breakthrough: Chloroquine phosphate has shown apparent efficacy in treatment of COVID-19 associated pneumonia in clinical studies. Biosci Trends. 2020;14(1):72-3. doi: 10.5 582/bst.2020.01047

36. Gautret P, Lagier JC, Parola P, Hoang VT, Meddeb L, Mailhe M, et al. Hydroxychloroquine and azithromycin as a treatment of COVID-19: Results of an open-label non-randomized clinical trial. Int J Antimicrob Agents. 2020;105949. doi: 10.1016/j.ijantimicag.2020.105949

37. Chen J, Liu D, Liu L, Liu P, Xu Q, Xia L, et al. A pilot study of hydroxychloroquine in treatment of patients with common coronavirus disease-19 (COVID-19). J Zhejiang Univ. 2020;49(2):215-9. doi: 10.3785/j.issn.1008-9292.2020.03.03

38. Popert A. Chloroquine: A review. Rheumatology. 1976;15(3):235-8. doi: 10. 1093/rheumatology/15.3.235

39. Multicenter collaboration group of Department of Science and Technology of Guangdong Province and Health Commission of Guangdong Province for chloroquine in the treatment of novel coronavirus pneumonia. Expert consensus on chloroquine phosphate for the treatment of novel coronavirus pneumonia. Zhonghua Jie $\mathrm{He} \mathrm{He} \mathrm{Hu} \mathrm{Xi}$ Za Zhi. 2020;43(3):185-8. doi: 10.3760/ cma.j.issn.1001-0939.2020.03.009

40. Dong L, Hu S, Gao J. Discovering drugs to treat coronavirus disease 2019 (COVID-19). Drug Discov Ther. 2020;14 (1):58-60. doi: 10.5582/ddt.2020.01012

41. Laaksonen AL, Koskiahde V, Juva K. Dosage of antimalarial drugs for children with juvenile rheumatoid arthritis and systemic lupus erythematosus. A clinical study with determination of serum concentrations of chloroquine and hydroxychloroquine. Scand J Rheumatol. 1974;3(2):103-8. doi: 10.3109/03009747 409115809

42. Boriskin YS, Leneva IA, Pecheur EI, Polyak SJ. Arbidol: A broad-spectrum antiviral compound that blocks viral fusion. Curr Med Chem. 2008;15(10):997-1005. doi: 10.2174/092986708784049658

43. Teissier E, Zandomeneghi G, Loquet A, Lavillette D, Lavergne JP, Montserret $\mathrm{R}$, et al. Mechanism of inhibition of enveloped virus membrane fusion by the antiviral drug arbidol. PLoS One. 2011;6(1):e15874. doi: 10.1371/journal.p one.0015874

44. Blaising J, Polyak SJ, Pécheur EI. Arbidol as a broad-spectrum antiviral: An update. Antiviral Res. 2014;107:84-94. doi: 10.1 016/j.antiviral.2014.04.006

45. Wu C, Liu Y, Yang Y, Zhang P, Zhong W, Wang Y, et al. Analysis of therapeutic targets for SARS-CoV-2 and discovery of potential drugs by computational methods. Acta Pharm Sinica B. 2020. doi: 10.1016/j. apsb.2020.02.008

46. Deng L, Li C, Zeng Q, Liu X, Li X, Zhang $\mathrm{H}$, et al. Arbidol combined with LPV/r versus LPV/r alone against corona virus disease 2019: A retrospective cohort study. J Infect. 2020;S0163-4453(20)30113-4. doi: 10.1016/j.jinf.2020.03.002

47. Wang Z, Chen X, Lu Y, Chen F, Zhang W. Clinical characteristics and therapeutic procedure for four cases with 2019 novel coronavirus pneumonia receiving combined Chinese and Western medicine treatment. Biosci Trends. 2020;14(1):648. doi: $10.5582 /$ bst. 2020.01030

48. Chan KW, Wong VT, Tang SCW. COVID-19: An update on the epidemiological, clinical, preventive and therapeutic evidence and guidelines of integrative Chinese-Western medicine 
for the management of 2019 novel coronavirus disease. Am J Chin Med. 2020;48(3):737-62. doi: 10.1142/S01924 $15 \times 20500378$

49. Parker WB. Metabolism and antiviral activity of ribavirin. Virus Res. 2005;107 (2):165-71. doi: 10.1016/j.virusres.2004. 11.006

50. Patterson JL, Fernandez-Larsson R. Molecular mechanisms of action of ribavirin. Rev Infect Dis. 1990;12(6):1139 -46. doi: 10.1093/clinids/12.6.1139

51. Graci JD, Cameron CE. Mechanisms of action of ribavirin against distinct viruses. Rev Med Virol. 2006;16(1):37-48. doi: 10.1002/rmv.483

52. Chu C, Cheng V, Hung I, Wong M, Chan $\mathrm{K}$, Chan K, et al. Role of lopinavir/ ritonavir in the treatment of SARS: Initial virological and clinical findings. Thorax. 2004;59(3):252-6. doi: 10.1136/thorax.2 003.012658

53. Momattin H, Al-Ali AY, Al-Tawfiq JA. A systematic review of therapeutic agents for the treatment of the Middle East Respiratory Syndrome Coronavirus (MERS-CoV). Travel Med Infect Dis. 2019;30(July-August 2019):9-18. doi: 10. 1016/j.tmaid.2019.06.012

54. Zeng YM, Xu XL, He XQ, Tang SQ, Li Y, Huang YQ, et al. Comparative effectiveness and safety of ribavirin plus interferon-alpha, lopinavir/ritonavir plus interferon-alpha and ribavirin plus lopinavir/ritonavir plus interferon-alphain in patients with mild to moderate novel coronavirus pneumonia. Chin Med J. 2020; 133(9):1132-4. doi: 10.1097/CM9.00000 00000000790

55. Kim UJ, Won EJ, Kee SJ, Jung SI, Jang HC. Combination therapy with lopinavir/ ritonavir, ribavirin and interferon- $\alpha$ for Middle East respiratory syndrome. Antivir Ther. 2016;21(5):455-9. doi: 10.3851IMP 3002
56. Furuta Y, Komeno T, Nakamura $T$. Favipiravir (T-705), a broad spectrum inhibitor of viral RNA polymerase. Proc Jpn Acad Ser B Phys Biol Sci. 2017;93 (7):449-63. doi: 10.2183/pjab.93.027

57. Delang L, Abdelnabi R, Neyts J. Favipiravir as a potential countermeasure against neglected and emerging RNA viruses. Antiviral Res. 2018;153:85-94. doi: 10.1016/j.antiviral.2018.03.003

58. Pharmaceutical Technology. China approves first anti-viral drug against coronavirus covid-19 [Diakses pada: 24 Maret 2020] Tersedia dari: https://www. pharmaceuticaltechnology.com/news/chi na-approves-favilavir-covid-19/

59. Bai CQ, Mu JS, Kargbo D, Song YB, Niu WK, Nie WM, et al. Clinical and virological characteristics of ebola virus disease patients treated with favipiravir (T-705)-Sierra Leone, 2014. Clin Infect Dis. 2016;63(10):1288-94. doi: 10.1093/ cid/ciw571

60. Sissoko D, Laouenan C, Folkesson E, M'Lebing AB, Beavogui AH, Baize S, et al. Experimental treatment with favipiravir for ebola virus disease (the JIKI trial): A historically controlled, single-arm proofof-concept trial in Guinea. PLoS Med. 2016;13(3):e1001967. doi: 10.1371/journ al.pmed.1001967

61. Saw Swee Hock School of Public Health-National University of Singapore. COVID-19 Science Report: Therapeutics 2020 [Diakses pada: 25 Maret 2020]. Tersedia dari: https://sph.nus.edu.sg/wp -content/uploads/2020/03/COVID-19-Sc ience-Report-Therapeutics-23-Mar.pdf

62. Cai Q, Yang M, Liu D, Chen J, Shu D, Xia J, et al. Experimental treatment with favipiravir for COVID-19: An open-label control study. Engineering. 2020. doi: 10. 1016/j.eng.2020.03.007

63. Chen C, Huang J, Cheng Z, Wu J, Chen S, Zhang Y, et al. Favipiravir versus arbidol 
for COVID-19: A randomized clinical trial 2020 [Diaksed pada: 23 Maret 2020]. Tersedia dari: https://www.medrxiv.org / content/10.1101/2020.03.17.20037432v 1.full.pdf

64. Sheahan TP, Sims AC, Leist SR, Schafer A, Won J, Brown AJ, et al. Comparative therapeutic efficacy of remdesivir and combination lopinavir, ritonavir, and interferon beta against MERS-CoV. Nat Comm. 2020;11(1):222. doi: 10.1038/s41 467-019-13940-6

65. Rock BM, Hengel SM, Rock DA, Wienkers LC, Kunze KL. Characterization of ritonavir-mediated inactivation of cytochrome P450 3A4. Mol Pharmacol. 2014;86(6):665-74. doi: 10.1124/mol.11 4.094862

66. Park SY, Lee JS, Son JS, Ko JH, Peck KR, Jung Y, et al. Post-exposure prophylaxis for Middle East respiratory syndrome in healthcare workers. J Hosp Infect. 2019; 101(1):42-6. doi: 10.1016/j.jhin.2018.09. 005

67. Lim J, Jeon S, Shin HY, Kim MJ, Seong YM, Lee WJ, et al. Case of the index patient who caused tertiary transmission of covid-19 infection in Korea: The application of lopinavir/ritonavir for the treatment of COVID-19 infected pneumonia monitored by quantitative RTPCR. J Korean Med Sci. 2020;35(6):e79. doi: 10.3346/jkms.2020.35.e79

68. Young BE, Ong SWX, Kalimuddin S, Low JG, Tan SY, Loh J, et al. Epidemiologic features and clinical course of patients infected with SARS-CoV-2 in Singapore. J Am Med Assoc. 2020;e203204. doi: 10. 1001/jama.2020.3204

69. Cao B, Wang Y, Wen D, Liu W, Wang J, Fan G, et al. A trial of lopinavir-ritonavir in adults hospitalized with severe covid-19. N Engl J Med. 2020;382:1787-99. doi: 10.1056/NEJMoa2001282

70. Baden LR, Rubin EJ. Covid-19 - The search for effective therapy. N Engl J Med. 2020;382:1851-2. doi: 10.1056/NEJMe2 005477

71. Kwak SS. Physicians work out treatment guidelines for coronavirus. Korean Biomed Rev. 2020 [Diakses pada: 30 Maret 2020]. Tersedia dari: http://www. koreabiomed.com/news/articleView.htm 1?idxno $=7428$

72. Sheahan TP, Sims AC, Graham RL, Menachery VD, Gralinski LE, Case JB, et al. Broad-spectrum antiviral GS-5734 inhibits both epidemic and zoonotic coronaviruses. Sci Trans1 Med. 2017;9 (396):eaal3653. doi: 10.1126/scitranslme d.aal3653

73. Agostini ML, Andres EL, Sims AC, Graham RL, Sheahan TP, Lu X, et al. Coronavirus susceptibility to the antiviral remdesivir (GS-5734) is mediated by the viral polymerase and the proofreading exoribonuclease. mBio. 2018;9(2):e0022 1-18. doi: 10.1128/mBio.00221-18

74. Tchesnokov EP, Feng JY, Porter DP, Götte M. Mechanism of inhibition of ebola virus RNA-Dependent RNA Polymerase by remdesivir. Viruses. 2019;11(4):326. doi: $10.3390 / \mathrm{v} 11040326$

75. Drug Bank. Remdesivir [Diakses pada: 26 Maret 2020]. Available from: https:// www.drugbank.ca/drugs/DB14761\#refer ence-A191379.

76. Joseph A. As the coronavirus spreads, a drug that once raised the world's hopes is given a second shot. 2020 [Diakses pada: 15 Maret 2020]. Tersedia dari: https:// www.statnews.com/2020/03/16/remdesv ir-surges-ahead-against-coronavirus/

77. Holshue ML, DeBolt C, Lindquist S, Lofy $\mathrm{KH}$, Wiesman J, Bruce H, et al. First case of 2019 novel coronavirus in the United States. N Engl J Med. 2020;382(10):92936. doi: 10.1056/NEJMoa2001191

78. Study to evaluate the safety and antiviral activity of remdesivir (GS-5734 ${ }^{\mathrm{TM}}$ ) in 
participants with moderate coronavirus disease (COVID-19) compared to standard of care treatment 2020 [Diakses pada: 28 Maret 2020]. Tersedia dari: https://clini caltrials.gov/ct2/show/NCT04292730

79. Study to evaluate the safety and antiviral activity of remdesivir (GS-5734 ${ }^{\mathrm{TM}}$ ) in participants with severe coronavirus disease (COVID-19). 2020 [Diakses pada: 28 Maret 2020] Tersedia dari: https:// clinicaltrials.gov/ct2/show/NCT04292899

80. Sakoulas G. Remdesivir: A promising antiviral against coronaviruses. 2020 [Diakses pada: 10 Maret 2020]. Tersedia dari: https://www.jwatch.org/ na50889/2 020/03/03/remdesivir-promising-antivira 1-againstcoronaviruses

81. Uyeki TM. Oseltamivir treatment of influenza in children. Clin Infect Dis. 2018; 66(10):1501-3. doi: 10.1093/cid/cix1150

82. Liu YC, Liao CH, Chang CF, Chou CC, Lin YR. A locally transmitted case of SARS-CoV-2 infection in Taiwan. N Engl J Med. 2020;382(11):1070-2. doi: 10.1056/NEJMc2001573

83. Rosa SGV, Santos WC. Clinical trials on drug repositioning for COVID-19 treatment. Rev Panam Salud Publica. 2020;44:e40. doi: 10.26633/RPSP.2020.40

84. Dandekar AA, Perlman S. Immunopathogenesis of coronavirus infections: Implications for SARS. Nat Rev Immunol. 2005;5(12):917-27. doi: 10. 1038/nri1732

85. Pfeffer LM, Dinarello CA, Herberman RB, Williams BRG, Borden EC, Bordens R, et al. Biological properties of recombinant $\alpha$-interferons: $40^{\text {th }}$ Anniversary of the discovery of interferons. Cancer Res. 1998; 58(12):2489-99.

86. Frieman M, Yount B, Heise M, KopeckyBromberg SA, Palese P, Baric RS. Severe acute respiratory syndrome coronavirus ORF6 antagonizes STAT1 function by sequestering nuclear import factors on the rough endoplasmic reticulum/golgi membrane. J Virol. 2007;81(18):9812-24. doi: 10.1128/JVI.01012-07

87. Yang Y, Ye F, Zhu N, Wang W, Deng Y, Zhao Z, et al. Middle East respiratory syndrome coronavirus ORF4b protein inhibits type I interferon production through both cytoplasmic and nuclear targets. Sci Rep.2015;5(November):1-13. doi: 10.1038/srep17554

88. Sun L, Xing Y, Chen X, Zheng Y, Yang $\mathrm{Y}$, Nichols DB, et al. Coronavirus papain-like proteases negatively regulate antiviral innate immune response through disruption of STING-mediated signaling. PLoS One. 2012;7(2):e30802. doi: 10.137 1/journal.pone.0030802

89. Daczkowski CM, Dzimianski JV, Clasman JR, Goodwin O, Mesecar AD, Pegan SD. Structural insights into the interaction of coronavirus papain-like proteases and interferon-stimulated gene product 15 from different species. J Mol Biol. 2017;429(11):1661-83. doi: 10.101 6/j.jmb.2017.04.011

90. Tan ELC, Ooi EE, Lin CY, Tan HC, Ling AE, Lim B, et al. Inhibition of SARS coronavirus infection in vitro with clinically approved antiviral drugs. Emerging Infectious Diseases. 2004;10(4): 581-6. doi: 10.3201/eid1004.030458 